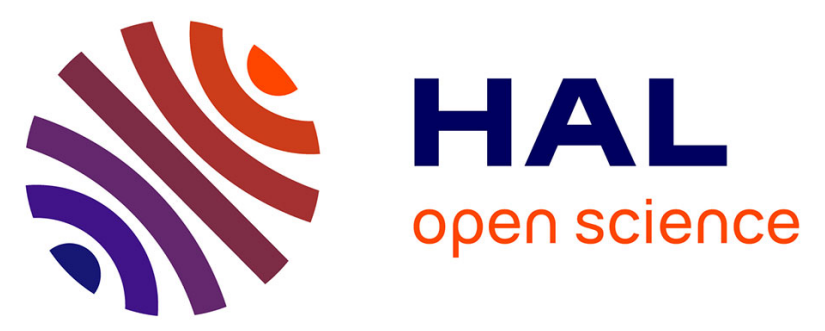

\title{
Improving the fracture toughness of stabilized zirconia-based solid oxide cells fuel electrode supports: Effects of type and concentration of stabilizer(s)
}

\author{
Peyman Khajavi, Peter Vang Hendriksen, Jérome Chevalier, Laurent
}

Gremillard, Henrik Lund Frandsen

\section{To cite this version:}

Peyman Khajavi, Peter Vang Hendriksen, Jérome Chevalier, Laurent Gremillard, Henrik Lund Frandsen. Improving the fracture toughness of stabilized zirconia-based solid oxide cells fuel electrode supports: Effects of type and concentration of stabilizer(s). Journal of the European Ceramic Society, 2020, 40 (15), pp.5670-5682. 10.1016/j.jeurceramsoc.2020.05.042 . hal-02922304

\section{HAL Id: hal-02922304 \\ https://hal.science/hal-02922304}

Submitted on 26 Aug 2020

HAL is a multi-disciplinary open access archive for the deposit and dissemination of scientific research documents, whether they are published or not. The documents may come from teaching and research institutions in France or abroad, or from public or private research centers.
L'archive ouverte pluridisciplinaire HAL, est destinée au dépôt et à la diffusion de documents scientifiques de niveau recherche, publiés ou non, émanant des établissements d'enseignement et de recherche français ou étrangers, des laboratoires publics ou privés. 


\title{
Improving the fracture toughness of stabilized zirconia-based solid oxide cells fuel electrode supports: Effects of type and concentration of stabilizer(s)
}

\author{
Published in the Journal of the European Ceramic Society (2020), vol. 40 (15) pp. 5670-5682
}

https://doi.org/10.1016/j.jeurceramsoc.2020.05.042t

\author{
Peyman Khajavi ${ }^{\mathrm{a}}$, Peter Vang Hendriksen ${ }^{\mathrm{a}}$, Jérôme Chevalier ${ }^{\mathrm{b}}$, \\ Laurent Gremillard ${ }^{\mathrm{b}}$, Henrik Lund Frandsen ${ }^{\mathrm{a}}$
}

\author{
${ }^{a}$ Department of Energy Conversion and Storage, Technical University of Denmark, Fysikvej, 2800 Kgs., Lyngby, \\ Denmark \\ ${ }^{\mathrm{b}}$ Univ Lyon, INSA-Lyon, CNRS, MATEIS UMR 5510, F-69621, Villeurbanne, France
}

\begin{abstract}
$\underline{\text { Abstract }}$
Further development and upscaling of the Solid Oxide fuel and electrolysis Cell (SOCs) technologies would significantly benefit from improvement of their mechanical robustness. In this work, microstructure, crystalline phase composition, fracture toughness and susceptibility to lowand high-temperature degradation of six different $\mathrm{Ni}(\mathrm{O})$-Zirconia fuel electrode supports, manufactured from six different stabilized zirconia compounds, are investigated.

In the oxidized state, tetragonal zirconia-based supports have higher fracture toughness than cubic zirconia-based substrate, due to the transformation toughening effect and a finer grained microstructure. The $\mathrm{NiO}-1.5 \mathrm{CeO}_{2} 4.5 \mathrm{YO}_{1.5}-\mathrm{SZ}$ support exhibits the highest fracture toughness, showing a 30 and $10 \%$ improvement compared to the state-of-the-art $\mathrm{NiO}-5.8 \mathrm{YO}_{1.5}$-SZ support at room temperature and $800{ }^{\circ} \mathrm{C}$, respectively. In the reduced state on the other hand, the tetragonal and cubic zirconia-based substrates have comparable fracture toughness. The Ceria-Yttria codoped materials possess superior resistance to hydrothermal degradation due to the stabilizing effect of $\mathrm{Ce}^{3+}$ formed during reduction.
\end{abstract}

\section{$\underline{\text { Keywords }}$}

Fracture toughness ; SOFC ; SOEC ; Ceria-Yttria co-doped ; Transformation toughening

\section{$\underline{\text { 1. Introduction }}$}

Solid Oxide fuel and Electrolysis cells (here referred to in general as solid oxide cells (SOCs)) are high temperature electrochemical devices that can, with a high electrical efficiency, be used for energy conversion applications [1,2]. Fuel electrode-supported planar SOC, where the substrate is located at the fuel side of the cells, is among the most common SOC configurations. This design 
typically includes thin $(<50 \mu \mathrm{m})$ electrochemical active layers (cathode, anode and electrolyte) supported by a relatively thick $(\sim 300 \mu \mathrm{m})$ substrate providing the mechanical stability [3-5].

Being made of intrinsically brittle ceramic components, the mechanical reliability of SOCs is a very significant issue for the use of the technology. The SOCs are subjected to various stresses during the cell fabrication, stack-assembly and in operation. A mismatch among the thermal expansion coefficients of the different materials of the cell causes residual stresses. Mechanical stresses can also be induced during cell handling and assembly into stacks. Furthermore, the stress field in a SOC stack is affected by the oxidation and reduction reactions, external mechanical loads and the non-homogeneous temperature distribution prevailing during operation [6-9] These stresses can create micro cracks and defects [10] and also result in the propagation of pre-existing cracks, which can cause the mechanical failure of the system.

Furthermore, crack growth in ceramics can happen at stress intensity factors below the fracture toughness of the material, through so-called slow (sub-critical) crack growth phenomenon. This results in the time dependent fracture behavior of ceramics $[11,12]$. As the structural reliability of SOCs is determined by the robustness of their support layer, improving the support's resistance to crack propagation and slow crack growth is essential to facilitate further developments of SOC technologies and up-scaling [13].

Fuel electrode support in SOCs is typically a porous composite made of stabilized zirconia (YSZ) and $\mathrm{NiO}$. By exposure to a reducing environment in the SOC stack, the $\mathrm{NiO}$ phase in this $\mathrm{NiO}-$ YSZ composite reduces to the metallic state, and the Ni-YSZ cermet (ceramic-metal) is formed. Presence of the Ni network results in the high electrical conductivity of the support, while the stabilized zirconia is needed to provide better thermal expansion compatibility to the adjacent ceramic components of the cell [14-16]. The mechanical properties of both the NiO-YSZ and NiYSZ are relevant to the technological use of the component, as the cells may fail both during stack assembly (oxidized state) and during operation (reduced state).

For the stabilized zirconia phase two stabilized zirconia compounds, namely 8 mol\% yttria doped zirconia (8YSZ) and 3 mol\% yttria doped zirconia (3YSZ), have mainly been used $[3,9,15,17,18]$. Fracture toughness and strength of 3YSZ, having a tetragonal crystalline phase, are typically several times higher than those of the cubic 8YSZ. This significant difference is predominantly a result of the tetragonal to monoclinic transformation toughening mechanism, a characteristic of ceramics containing the transformable tetragonal zirconia phase [19]. Consequently, the 3YSZ based SOC supports are found to be stronger and tougher compared to the $8 \mathrm{YSZ}$ ones. For instance, Pećanac and co-workers [18] found the room temperature fracture toughness of NiO$3 \mathrm{YSZ}$ and NiO-8YSZ supports to be 3.05 and $1.76 \mathrm{MPa} \mathrm{m}^{1 / 2}$, respectively. Radovic and LaraCurzio [15] reported the room temperature fracture toughness of NiO-8YSZ to be $2.1 \mathrm{MPa} \mathrm{m}^{1 / 2}$. The NiO-3YSZ has the highest fracture toughness values reported for SOC supports, and thus it is considered as the state-of-the-art in terms of mechanical robustness.

A comparison between the fracture toughness and strength of the 3YSZ and 8YSZ based supports suggests that a further improvement in the mechanical properties of SOC supports is achievable if a stabilized zirconia compound capable of providing a higher transformation toughening effect is used. It is therefore relevant to consider the transformation toughening mechanism in more details.

The tetragonal to monoclinic phase transformation in zirconia is associated with a volume expansion and shear strain of approximately 4 and $16 \%$, respectively [19]. This phase transformation can be induced by external stresses. The transformation toughening in a tetragonal zirconia-containing ceramic thus occurs when the stress field around a propagating crack triggers 
the tetragonal to monoclinic phase transformation. The resulting volume expansion exerts a compressive stress on the process zone around the crack tip, which tends to close the crack. In other words, it decreases the stress intensity factor at the crack tip. The stress induced tetragonal to monoclinic transformation may also result in other phenomena, such as microcracking and crack deflection around the crack tip, consequently providing an additional toughening [19-21].

To benefit from the transformation toughening mechanism, it is necessary to retain the tetragonal phase upon cooling from the typical high sintering temperatures $\left(>1000{ }^{\circ} \mathrm{C}\right)$, operation at high temperature $\left(\approx 800{ }^{\circ} \mathrm{C}\right)$ and through thermal cycling. Stabilization of the tetragonal phase is typically achieved by doping zirconia with other cations, such as yttrium or cerium [22]. An effective transformation toughening is achieved if suitable amounts of stabilizer(s) are chosen, such that the tetragonal phase stays stable up to the service temperature while still having enough "transformability" to the monoclinic phase. In other words, "over-stabilization" of the tetragonal phase should be avoided [20-23].

When considering the mechanical properties of tetragonal zirconia based ceramics, it is also important to take the degradation (aging) issues into account. If the tetragonal zirconia is highly transformable, the tetragonal to monoclinic phase transformation can happen too readily, even without applying an external load. The corresponding volume expansion negatively influences the mechanical properties of the material. This phenomenon is in particular important at low temperatures, i.e. below $400{ }^{\circ} \mathrm{C}$ (the so-called low-temperature degradation, LTD) [21]. It can also occur at higher temperatures. Lin and Duh [24,25] observed that aging the ceria-doped and yttriadoped zirconia at high temperatures can cause the tetragonal to monoclinic phase transformation to occur athermally upon the subsequent cooling to room temperature, and even isothermally during aging. The extent of the transformation depended on the temperature and duration of aging, and the stabilizer concentration in the compound.

Yttrium and cerium are two common dopants used to stabilize the tetragonal zirconia to room temperature. Ceria doped tetragonal zirconia ceramics exhibit higher fracture toughness and are more resistant to LTD, while yttria doped tetragonal zirconia possesses higher strength [23]. Codoping the zirconia with cerium and yttrium has been shown to be a promising approach to achieve a combination of good fracture toughness, strength and resistance to LTD [26-29]. Despite the fact that aging of tetragonal zirconia ceramics is well investigated, studies on the aging of tetragonal zirconia-based SOC supports, when the material is part of a porous cermet, are rare in literature.

In a previous study [30] we developed transformation boundary diagrams for Ce-Y co-doped zirconia, applicable for different temperatures and degrees of powder packing. With this, it is possible to choose the optimum amount of stabilizing agents such that the tetragonal phase has enough stability; yet not being over-stabilized. It should be noted that the sintering temperature and density of the tetragonal zirconia ceramic are important parameters affecting the stability of the tetragonal phase, and should be considered when choosing the stabilizer concentration [30-32].

In this study, six zirconia compounds with different stabilizer contents (Table 1) were used as the stabilized zirconia phase in the SOCs fuel electrode supports. Four compounds were identified by said previous study [30]. The fracture toughness values of the supports manufactured using these four compounds were compared to the state-of-the-art material, 3 YSZ (denoted in this paper as $5.8 \mathrm{YO}_{1.5}-\mathrm{SZ}$ ) and the widely used $8 \mathrm{YSZ}$ (denoted as $14.8 \mathrm{YO}_{1.5}-\mathrm{SZ}$ ) based supports. Fracture toughness measurements were performed at room temperature and $800{ }^{\circ} \mathrm{C}$ for both pristine (oxidized) and reduced samples. Moreover, the effect of long term aging at $800{ }^{\circ} \mathrm{C}$ on the crystalline phase and fracture toughness of tetragonal zirconia based samples was investigated. 


\section{Experimental}

\subsection{Sample preparation}

The samples studied in this work and the stabilizer contents of their zirconia phase are presented in Table 1. The six types of SOCs fuel electrode supports were prepared from a mixture of $\mathrm{NiO}$ (Alfa Aesar) and six different stabilized zirconia compounds. The NiO/zirconia composition of the supports was 55/45 (wt\%). The stabilizer contents of the new zirconia materials was such chosen to bring the compounds very close to the transformation boundary line for porous ceramics, presented in Figure 5 of ref. [30]. The yttria doped and ceria-yttria co-doped compounds were purchased from Tosoh (TOSOH, Japan) and Nanoe (Nanoe, France), respectively.

Table 1. Samples studied in this work and compositions of the stabilized zirconia (SZ) phase (for instance, $\mathrm{NiO}-1.5 \mathrm{CeO} 2$

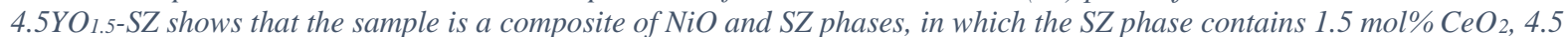
mol\% $\mathrm{YO}_{1.5}$ and $94 \mathrm{~mol} \% \mathrm{ZrO}_{2}$; accordingly, the notations used for 2.5YSZ, 3YSZ and 8YSZ are 4.9YO $\mathrm{Y}_{1.5-}-\mathrm{SZ}, 5.8 Y \mathrm{O}_{1.5-}-\mathrm{SZ}_{\text {and }}$ 14.8YO $1.5-\mathrm{SZ}$, respectively).

\begin{tabular}{|c|c|c|c|}
\hline \multirow[t]{2}{*}{ Sample notation } & \multicolumn{2}{|c|}{ Stabilizer content of the SZ phase } & \multirow{2}{*}{$\begin{array}{c}\text { Supplier of the SZ } \\
\text { material }\end{array}$} \\
\hline & $\mathrm{Ce}(\mathrm{mol} \%)$ & Y $(\mathrm{mol} \%)$ & \\
\hline $\mathrm{NiO}-14.8 \mathrm{YO}_{1.5}-\mathrm{SZ}$ & - & 14.8 & Tosoh \\
\hline $\mathrm{NiO}-5.8 \mathrm{YO}_{1.5}-\mathrm{SZ}$ & - & 5.8 & Tosoh \\
\hline $\mathrm{NiO}-4.9 \mathrm{YO}_{1.5}-\mathrm{SZ}$ & - & 4.9 & Tosoh \\
\hline $\mathrm{NiO}-1.5 \mathrm{CeO}_{2} 4.5 \mathrm{YO}_{1.5-\mathrm{SZ}}$ & 1.5 & 4.5 & Nanoe \\
\hline $\mathrm{NiO}-3 \mathrm{CeO}_{2} 3.6 \mathrm{YO}_{1.5}-\mathrm{SZ}$ & 3 & 3.6 & Nanoe \\
\hline $\mathrm{NiO}-5 \mathrm{CeO}_{2} 3 \mathrm{YO}_{1.5}-\mathrm{SZ}$ & 5 & 3 & Nanoe \\
\hline $1.5 \mathrm{CeO}_{2} 4.5 \mathrm{YO}_{1.5-\mathrm{SZ}}$ & 1.5 & 4.5 & Nanoe \\
\hline $4.9 \mathrm{YO}_{1.5-\mathrm{SZ}}$ & - & 4.9 & Tosoh \\
\hline
\end{tabular}

In addition to NiO-zirconia supports, plain zirconia samples were also prepared (Table 1). The plain zirconia samples were used for microstructural and crystalline phase analyses.

All samples were prepared by tape casting [33,34]. The tape casting slurries were made using a mixture of methyl ethyl ketone (MEK) and ethanol as solvent, polyvinylpyrrolidone (PVP) as dispersant and an in-house formulated binder, and were casted onto a Mylar® foil using a stationary doctor blade. The $\mathrm{NiO}$-zirconia and plain zirconia green tapes were sintered at 1320 and $1340{ }^{\circ} \mathrm{C}$, respectively. The average thickness of the samples after sintering was $200-300 \mu \mathrm{m}$.

The sintered NiO-zirconia supports were laser cut into specimens with dimension of $40 \times 20 \mathrm{~mm}^{2}$ for mechanical testing. On each specimen a notch was laser cut (10 $\mathrm{mm}$ long and $0.5 \mathrm{~mm}$ wide). The last $2 \mathrm{~mm}$ of the notch was cut with a V-shape, to sharpen the notch and facilitate straight crack propagation. The specimen and notch geometries are shown in Figure 1a.

Some of the specimens were reduced in a tube furnace (in $4 \% \mathrm{H}_{2} / \mathrm{N}_{2}$ ) to achieve Ni-SZ samples for fracture toughness measurements. The reduction was performed at $900{ }^{\circ} \mathrm{C}$ for $5 \mathrm{~h}$. Moreover, some of the samples were reduced at $800{ }^{\circ} \mathrm{C}$ for 2 and $9 \mathrm{~h}$, and used for the low-temperature degradation (LTD) study. All pristine samples to be reduced were exposed to the reducing atmosphere once the furnace temperature reached the desired reduction temperature [17].

For high-temperature degradation (referred to hereinafter as HTD) study, the samples were aged at $800{ }^{\circ} \mathrm{C}$ for 200 and $850 \mathrm{~h}$. The HTD experiments were carried out in a humid reducing atmosphere, i.e. $3 \% \mathrm{H}_{2} \mathrm{O} / 4 \% \mathrm{H}_{2} / \mathrm{N}_{2}$ (the $4 \% \mathrm{H}_{2} / \mathrm{N}_{2}$ gas was humidified using a gas bubbler filled 
with DI water at room temperature). The temperature and atmosphere for HTD experiment was chosen considering the typical operating conditions of SOCs.

The LTD study was conducted by aging the samples in steam at $104{ }^{\circ} \mathrm{C}$ for $2.5 \mathrm{~h}$.

(a)

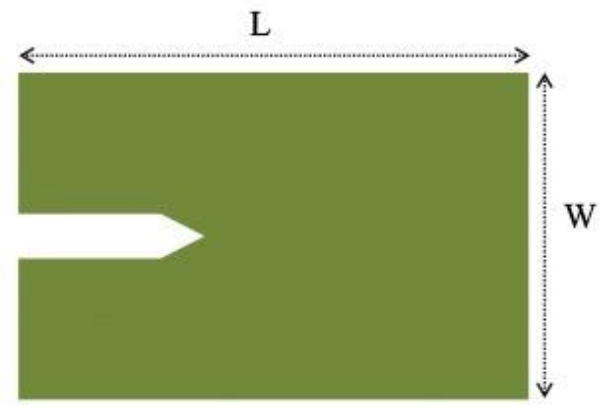

(b)

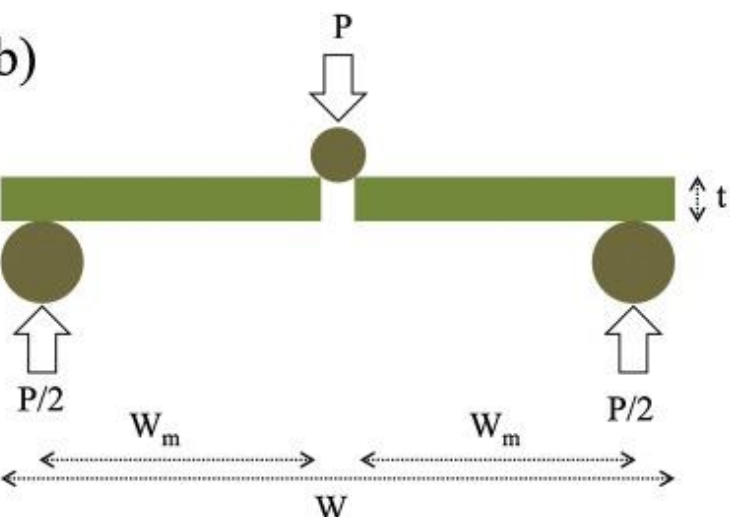

(c)
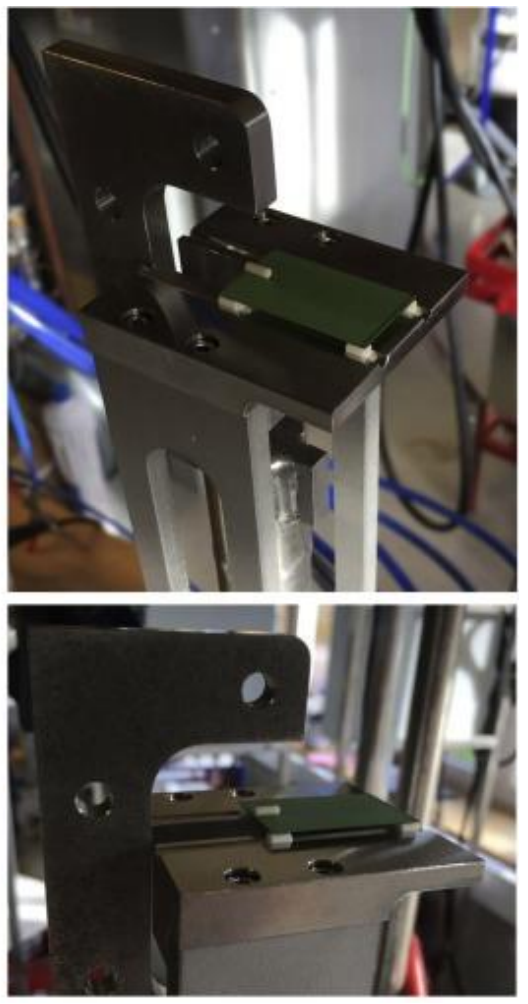

Figure 1. (a) Specimen and notch geometries, (b) loading configuration and (c) double torsion set-up.

\subsection{Characterization}

Fracture toughness of the oxidized and reduced samples at both room and high temperatures was determined using the double torsion method. The loading configuration and double torsion set-up are presented in Figure $1 \mathrm{~b}$ and $\mathrm{c}$, respectively. The double torsion tests were conducted using a crosshead speed of $0.6 \mathrm{~mm} \mathrm{~min}^{-1}$ and the load-displacement curves were recorded.

The stress intensity factor, $K_{I}$, for a double torsion test is given by [35]:

$$
K_{I}=\frac{P \times W_{m}}{t^{2}}\left(\frac{3(1+\psi)}{W \times \psi(t, W)}\right)^{1 / 2}
$$

where $P$ is the applied load (obtained at the plateau value of the load-displacement curves), $W_{m}$ is the moment arm, $W$ and $t$ are the width and thickness of the specimen, respectively and $v$ is the Poisson ratio. $\psi$ is a correction factor for specimen thickness [36]:

$$
\psi(t, W)=1-1.2604\left(\frac{t}{W}\right)+2.4\left(\frac{t}{W}\right) \exp \left(\frac{-\pi W}{2 t}\right)
$$

Preliminary tests on specimens with and without pre-cracking resulted in similar plateau loads. The possibility to conduct the double torsion tests on specimen without pre-cracking for thin specimens has also reported by Pećanac and co-workers [18]. However, a precise sample alignment is required. In samples without pre-cracking the optical microscopy observation showed 
that the crack has propagated approximately $2-3 \mathrm{~mm}$ once the plateau is achieved, which remains in the range where $K_{I}$ can be considered as independent of the crack length in double torsion test.

For the high temperature tests of the reduced samples, heating in the mechanical test rig was done in $4 \% \mathrm{H}_{2} / \mathrm{N}_{2}$, to avoid the re-oxidation of the reduced samples.

The morphology of polished and thermally etched samples was studied by Field Emission Scanning Electron Microscopy (FE-SEM, Merlin, Carl Zeiss, Germany). The thermal etching was carried out at $50{ }^{\circ} \mathrm{C}$ below the sintering temperature for $0.5 \mathrm{~h}$, with heating and cooling rates of $480{ }^{\circ} \mathrm{C} \mathrm{h}^{-1}$. The average grain size of the stabilized zirconia in the NiO-SZ and plain SZ samples was determined by measuring the size of ca. 150 grains (for each type of sample). Porosity of the samples was determined from their mass and geometrical dimensions.

Phase identification of the samples in the pristine and reduced states was carried out using X-ray diffraction (XRD, Bruker D8, Bruker, Germany) using $\mathrm{Cu} \mathrm{K \alpha}$ radiation. A wide scan (with step size and scan speed of $0.03^{\circ}$ and $0.015^{\circ} \mathrm{s}^{-1}$, respectively) over the range of 10-90 and two high resolution scans (with step size and scan speed of $0.003^{\circ}$ and $0.0015^{\circ} \mathrm{s}^{-1}$, respectively) over the ranges of $25.5-33.5^{\circ}$ and $70.5-76.5^{\circ}$ were performed. From the high resolution scan over $70.5-$ $76.5^{\circ}$, no presence of the tetragonal and cubic zirconia mixtures in the samples was observed.

Volume fraction of the monoclinic phase $\left(V_{m}\right)$, once detected, was calculated using the method proposed by Toraya and co-workers [37].

$$
\begin{aligned}
& X_{m}=\frac{I_{m}^{(11 \overline{1})}+I_{m}^{(111)}}{I_{m}^{(11 \overline{1})}+I_{m}^{(111)}+I_{i}^{(101)}} \\
& V_{m}=\frac{1.311 \times X_{m}}{1+0.311 \times X_{m}}
\end{aligned}
$$

where $X_{m}$ is the integrated intensity ratio, derived from the integrated peak intensities of the (101)t, $(111)_{\mathrm{m}}$ and $(\overline{1} 11)_{m}$ planes. The subscripts $m$ and $t$ represent the monoclinic and tetragonal phases, respectively.

In addition, XRD and Raman spectroscopy were used to study the presence of the monoclinic phase in fractured surfaces. The preliminary investigations showed that the monoclinic phase could not be detected using XRD considering the thin and porous fractured surfaces of the samples. Nevertheless, Raman spectroscopy gave more reliable results, and was thus used for identification of the monoclinic phase in fractured surfaces. Raman spectra were obtained in a Renishaw InVia spectrometer, using a $532 \mathrm{~nm}$ wavelength Ar-ion laser and $20 \mathrm{~s}$ exposure time. The method suggested by Kim and co-workers [38] was used to estimate the monoclinic content of the fractured surfaces $\left(f_{m}\right)$ :

$$
\begin{aligned}
& X_{m}=\frac{I_{m}\left(180 \mathrm{~cm}^{-1}\right)+I_{m}\left(192 \mathrm{~cm}^{-1}\right)}{I_{m}\left(180 \mathrm{~cm}^{-1}\right)+I_{m}\left(192 \mathrm{~cm}^{-1}\right)+I_{t}\left(148 \mathrm{~cm}^{-1}\right)} \\
& f_{m}=\sqrt{0.19-\frac{0.13}{X_{m}-1.01}}-0.56
\end{aligned}
$$

where $I_{m}$ and $I_{t}$ are the intensity of the monoclinic and tetragonal peaks, respectively (at the specified Raman shifts) calculated after a baseline correction [38]. 


\section{Results}

\subsection{Crystalline phases and microstructure}

Figure 2 shows typical SEM micrographs of polished and thermally etched NiO-SZ and plain SZ samples. As presented in

Table 2, the average grain size of the zirconia phase in the $\mathrm{NiO}-14.8 \mathrm{YO}_{1.5}-\mathrm{SZ}$ is significantly higher than in the other supports. This is consistent with previous studies, where $8 \mathrm{~mol} \%$ yttria doped zirconia ceramics showed larger grains than zirconia stabilized with lower amount of yttria, namely less than 4 mol\% yttria, while sintered under the same conditions, see e.g. refs. [39-42].

Table 2. Average grain size and crystalline phase composition of the as-sintered NiO-SZ and plain SZ samples.

\begin{tabular}{|c|c|c|c|c|}
\hline \multirow[t]{2}{*}{ Sample notation } & \multirow[t]{2}{*}{ Grain size ${ }^{\mathrm{a}}(\mathrm{nm})$} & \multicolumn{3}{|c|}{ Crystalline phase composition (Vol\%) } \\
\hline & & Tetragonal & Monoclinic & Cubic \\
\hline $\mathrm{NiO}-14.8 \mathrm{YO}_{1.5} \mathrm{-SZ}$ & $1129(429)$ & 0 & 0 & 100 \\
\hline $\mathrm{NiO}-5.8 \mathrm{YO}_{1.5}-\mathrm{SZ}$ & $226(94)$ & 100 & 0 & 0 \\
\hline NiO-4.9YO1.5-SZ & $288(117)$ & 98.1 & 1.9 & 0 \\
\hline $\mathrm{NiO}-1.5 \mathrm{CeO}_{2} 4.5 \mathrm{YO}_{1.5-\mathrm{SZ}}$ & $283(138)$ & 95.6 & 4.4 & 0 \\
\hline $\mathrm{NiO}-3 \mathrm{CeO}_{2} 3.6 \mathrm{YO}_{1.5-\mathrm{SZ}}$ & $313(131)$ & 99.1 & 0.9 & 0 \\
\hline $\mathrm{NiO}-5 \mathrm{CeO}_{2} 3 \mathrm{YO}_{1.5-\mathrm{SZ}}$ & $327(128)$ & 99.5 & 0.5 & 0 \\
\hline $1.5 \mathrm{CeO}_{2} 4.5 \mathrm{YO}_{1.5}-\mathrm{SZ}$ & $275(135)$ & 100 & 0 & 0 \\
\hline $4.9 \mathrm{YO}_{1.5}-\mathrm{SZ}$ & $188(77)$ & 100 & 0 & 0 \\
\hline
\end{tabular}

a Numbers in parentheses show the standard deviation.

The average grain size of other samples lies between 250 and $330 \mathrm{~nm}$ and a relatively narrow grain size distribution is observed (

Table 2). Furthermore, as seen the $\mathrm{NiO}-5 \mathrm{CeO}_{2} 3 \mathrm{YO}_{1.5}-\mathrm{SZ}$ has slightly larger grain size. For the plain zirconia samples, a larger average grain size is seen in the $1.5 \mathrm{CeO}_{2} 4.5 \mathrm{YO}_{1.5} \mathrm{SZ}$ compared to the $4.9 \mathrm{YO}_{1.5}-\mathrm{SZ}$. This is well in line with literature findings when, for a given thermal treatment ceria doped zirconia ceramics develop larger grains than the yttria doped ones $[43,44]$.

Phase compositions of the plain and composite samples (

Table 2) show that the $\mathrm{NiO}-14.8 \mathrm{YO}_{1.5}-\mathrm{SZ}$ and $\mathrm{NiO}-5.8 \mathrm{YO}_{1.5}-\mathrm{SZ}$ contains only cubic and tetragonal zirconia, respectively. The other composite samples are predominantly tetragonal with low amounts of monoclinic phase (less than $5 \%$ ). The $4.9 \mathrm{YO}_{1.5}-\mathrm{SZ}$ and $1.5 \mathrm{CeO}_{2} 4.5 \mathrm{YO}_{1.5}-\mathrm{SZ}$ plain samples contain only the tetragonal phase. 

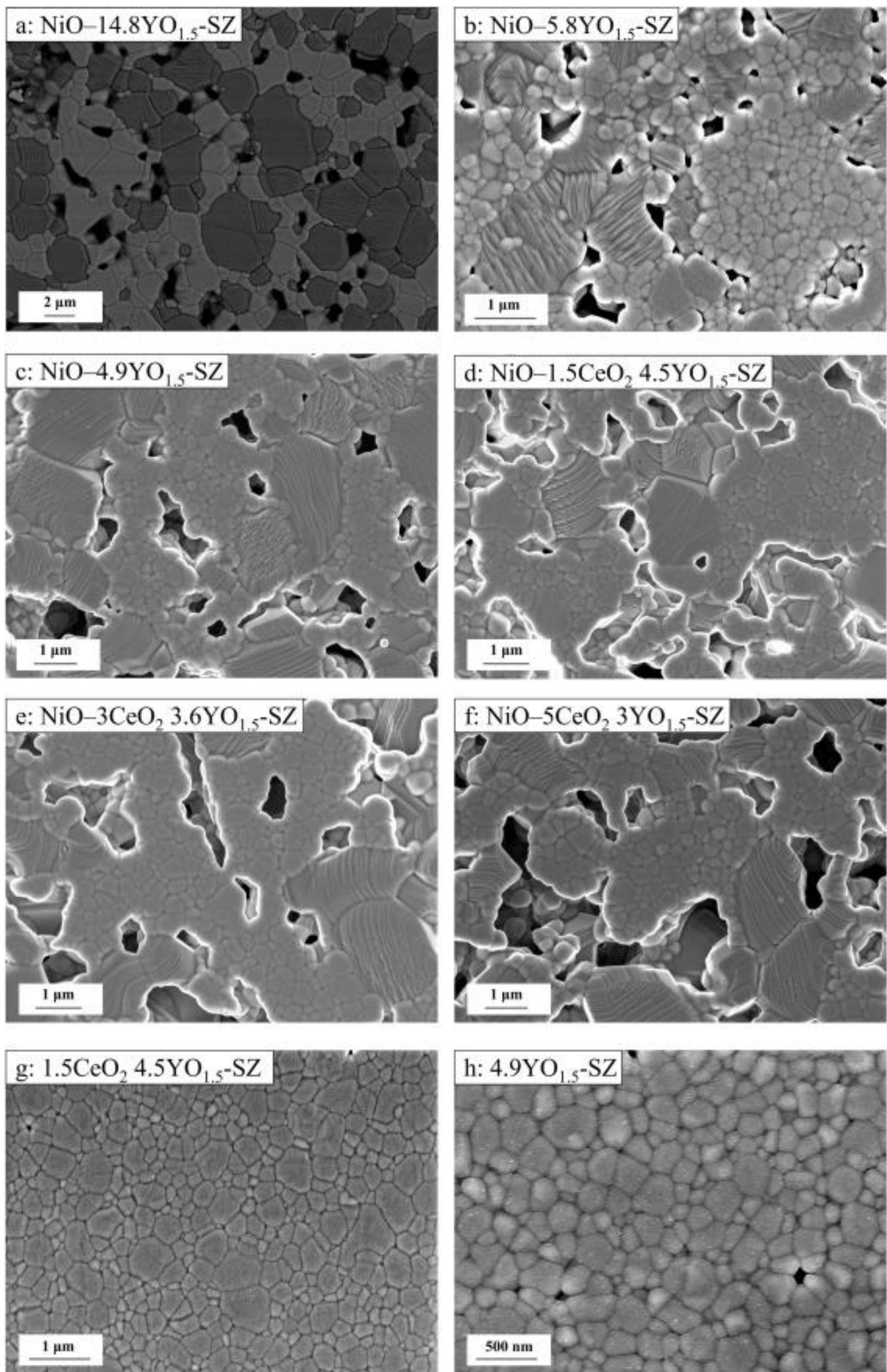

Figure 2. SEM micrographs of the polished and thermally etched $\mathrm{NiO}-\mathrm{SZ}$ and plain SZ samples. In (a) to (f), the smaller grains are zirconia, the larger grains are $\mathrm{NiO}$. 


\subsubsection{Oxidized supports}

Room temperature fracture toughness of the supports in the oxidized state is shown inFigure 3. The toughness of all the tetragonal zirconia-based supports is significantly higher than that of $\mathrm{NiO}-$ $14.8 \mathrm{YO}_{1.5}$-SZ, i.e. the composite containing cubic zirconia. The toughness of the $\mathrm{NiO}-3 \mathrm{CeO}_{2}$ $3.6 \mathrm{YO}_{1.5}-\mathrm{SZ}$ and $\mathrm{NiO}-5 \mathrm{CeO}_{2} 3 \mathrm{YO}_{1.5}-\mathrm{SZ}$ supports are comparable to that of $\mathrm{NiO}-5.8 \mathrm{YO}_{1.5}-\mathrm{SZ}$ support. For all samples, a decreasing trend in toughness with increasing porosity is observed, and the trend is more pronounced in the tetragonal zirconia based samples.

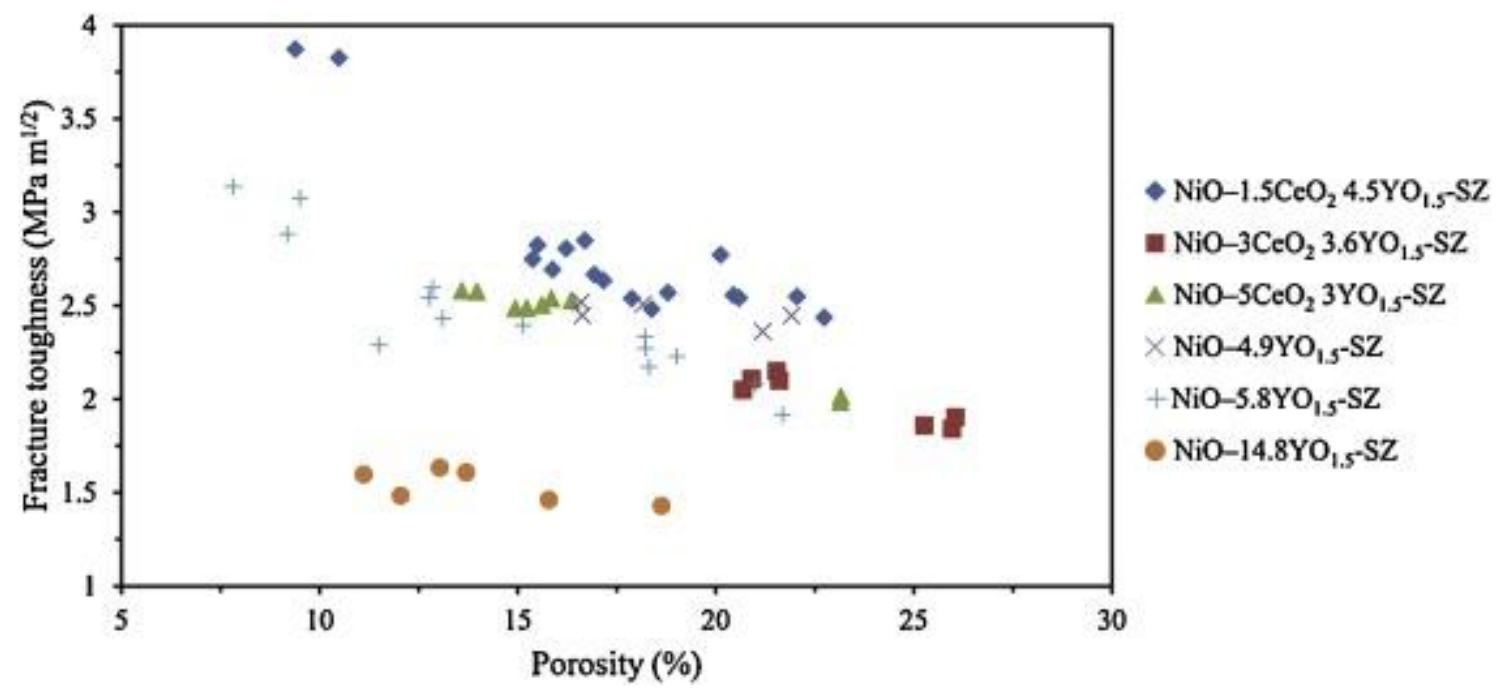

Figure 3. Fracture toughness of NiO-SZ supports with different stabilized zirconia compounds and porosities measured at room temperature (each data point represents a single measurement; uncertainty of the measured values is in the range of 3-5 \%).

More interestingly it is that the $\mathrm{NiO}-4.9 \mathrm{YO}_{1.5}-\mathrm{SZ}$ and $\mathrm{NiO}-1.5 \mathrm{CeO}_{2} 4.5 \mathrm{YO}_{1.5}-\mathrm{SZ}$ have a higher fracture toughness than the $\mathrm{NiO}-5.8 \mathrm{YO}_{1.5}-\mathrm{SZ}$, which is the state-of-the-art material for SOC supports.

The $\mathrm{NiO}-1.5 \mathrm{CeO}_{2} 4.5 \mathrm{YO}_{1.5}-\mathrm{SZ}$ support possesses the highest fracture toughness. Compared to the $\mathrm{NiO}-5.8 \mathrm{YO}_{1.5}$-SZ support, it shows an improvement of approximately 20 and $30 \%$ at the porosities of $15-20 \%$ and $10 \%$, respectively.

Figure 4 shows the fracture toughness of the oxidized samples measured at $800{ }^{\circ} \mathrm{C}$ in comparison to room temperature values. The fracture toughness of the tetragonal zirconia based supports decreases at $800{ }^{\circ} \mathrm{C}$, while it remains unchanged in the cubic zirconia based substrate (NiO14.8 $\mathrm{YO}_{1.5}$-SZ). Moreover, there is a tendency that the difference between the room and high temperature values decreases with increasing porosity.

With the available porosity-toughness data it is concluded that the $\mathrm{NiO}-1.5 \mathrm{CeO}_{2} 4.5 \mathrm{YO}_{1.5}-\mathrm{SZ}$ support has the highest toughness at $800{ }^{\circ} \mathrm{C}$, while the other tetragonal zirconia samples have comparable toughness. Compared to the NiO-5.8 $\mathrm{YO}_{1.5}-\mathrm{SZ}$, the $\mathrm{NiO}-1.5 \mathrm{CeO}_{2} 4.5 \mathrm{YO}_{1.5}-\mathrm{SZ}$ support shows an approximately $10 \%$ improvement in fracture toughness at $800{ }^{\circ} \mathrm{C}$ (The room and high temperature fracture toughness of $\mathrm{NiO}-1.5 \mathrm{CeO}_{2} 4.5 \mathrm{YO}_{1.5}-\mathrm{SZ}$ and $\mathrm{NiO}-5.8 \mathrm{YO}_{1.5}-\mathrm{SZ}$ are summarized in Figure 9 in the Appendix A. Supplementary data). Furthermore, fracture toughness of the tetragonal zirconia supports is still significantly higher than that of their cubic zirconia counterpart. 

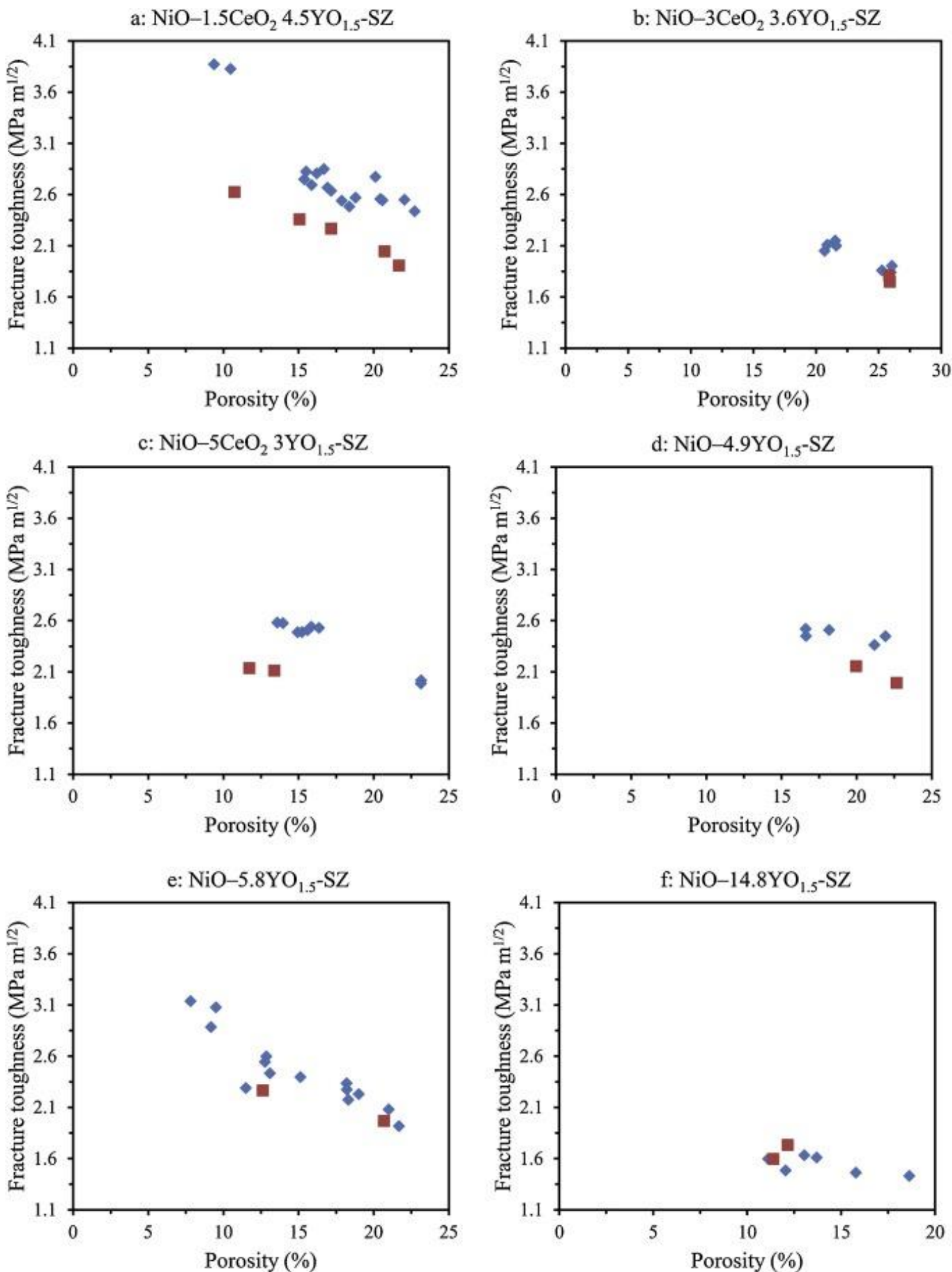

Figure 4. Fracture toughness of $\mathrm{NiO}-\mathrm{SZ}$ supports measured at room temperature (diamond symbols) and $800{ }^{\circ} \mathrm{C}$ (square symbols). Each data point represents a single measurement. 
Fracture toughness of the $\mathrm{NiO}-1.5 \mathrm{CeO}_{2} 4.5 \mathrm{YO}_{1.5}-\mathrm{SZ}$ and $\mathrm{NiO}-14.8 \mathrm{YO}_{1.5}-\mathrm{SZ}$ supports measured at room temperature, 250 and $800{ }^{\circ} \mathrm{C}$ is shown inFigure 5. For comparison, fracture toughness of $\mathrm{NiO}-5.8 \mathrm{YO}_{1.5}-\mathrm{SZ}$ measured at room temperature and $800{ }^{\circ} \mathrm{C}$ is also presented in the figure. The tetragonal and cubic zirconia-based supports had an average porosity of $\approx 20.5$ and $12.5 \%$, respectively. The fracture toughness of the $\mathrm{NiO}-1.5 \mathrm{CeO}_{2} 4.5 \mathrm{YO}_{1.5}-\mathrm{SZ}$ support at $250{ }^{\circ} \mathrm{C}$ is slightly lower compared to that at room temperature, whereas the decrease in fracture toughness is accelerated by further increasing the temperature to $800{ }^{\circ} \mathrm{C}$. In contrast, the $\mathrm{NiO}-14.8 \mathrm{YO}_{1.5-\mathrm{SZ}}$ support shows rather constant fracture toughness at the three temperatures.

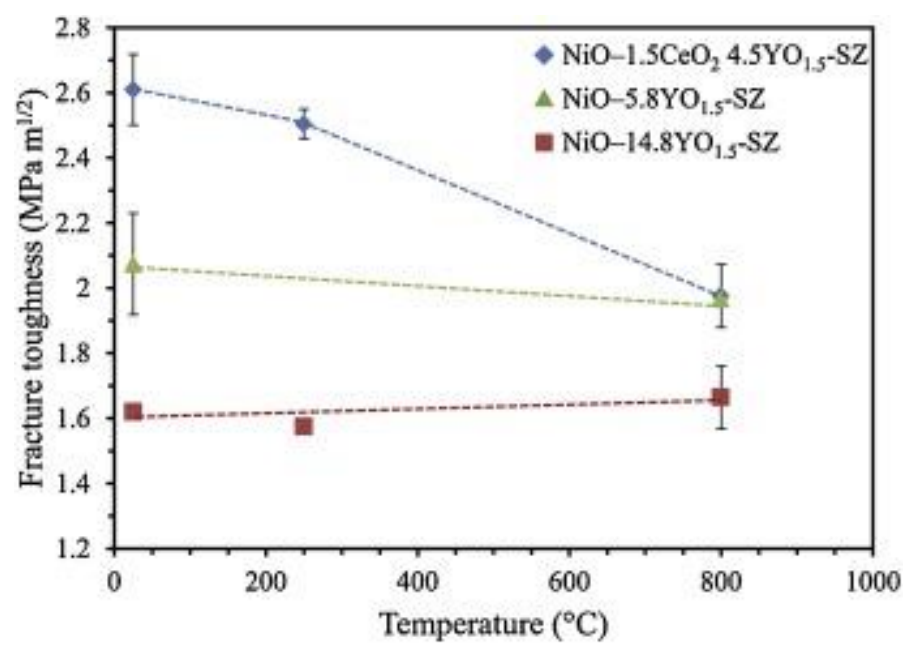

Figure 5. Fracture toughness of $\mathrm{NiO}-1.5 \mathrm{CeO}_{2}$ 4.5YO $1.5-\mathrm{SZ}$ and $\mathrm{NiO}-14.8 \mathrm{YO}_{1.5} \mathrm{-SZ}$ at room temperature, 250 and $800{ }^{\circ} \mathrm{C}$. For comparison, fracture toughness of $\mathrm{NiO}-5.8 \mathrm{YO}_{1.5}-\mathrm{SZ}$ measured at room temperature and $800{ }^{\circ} \mathrm{C}$ is also shown.

\subsubsection{Reduced supports}

Fracture toughness of the reduced $1.5 \mathrm{CeO}_{2} 4.5 \mathrm{YO}_{1.5}-\mathrm{SZ}-, 5.8 \mathrm{YO}_{1.5}-\mathrm{SZ}$ - and $14.8 \mathrm{YO}_{1.5}-\mathrm{SZ}$-based supports at room temperature and $800{ }^{\circ} \mathrm{C}$ is presented inFigure 6 . The difference between the fracture toughness values of the reduced tetragonal- and cubic zirconia-based supports is not as pronounced as in the oxidized state. The samples have comparable fracture toughness and the $1.5 \mathrm{CeO}_{2} 4.5 \mathrm{YO}_{1.5}-\mathrm{SZ}$ based support possesses slightly higher fracture toughness considering that the porosity of the sample is higher.

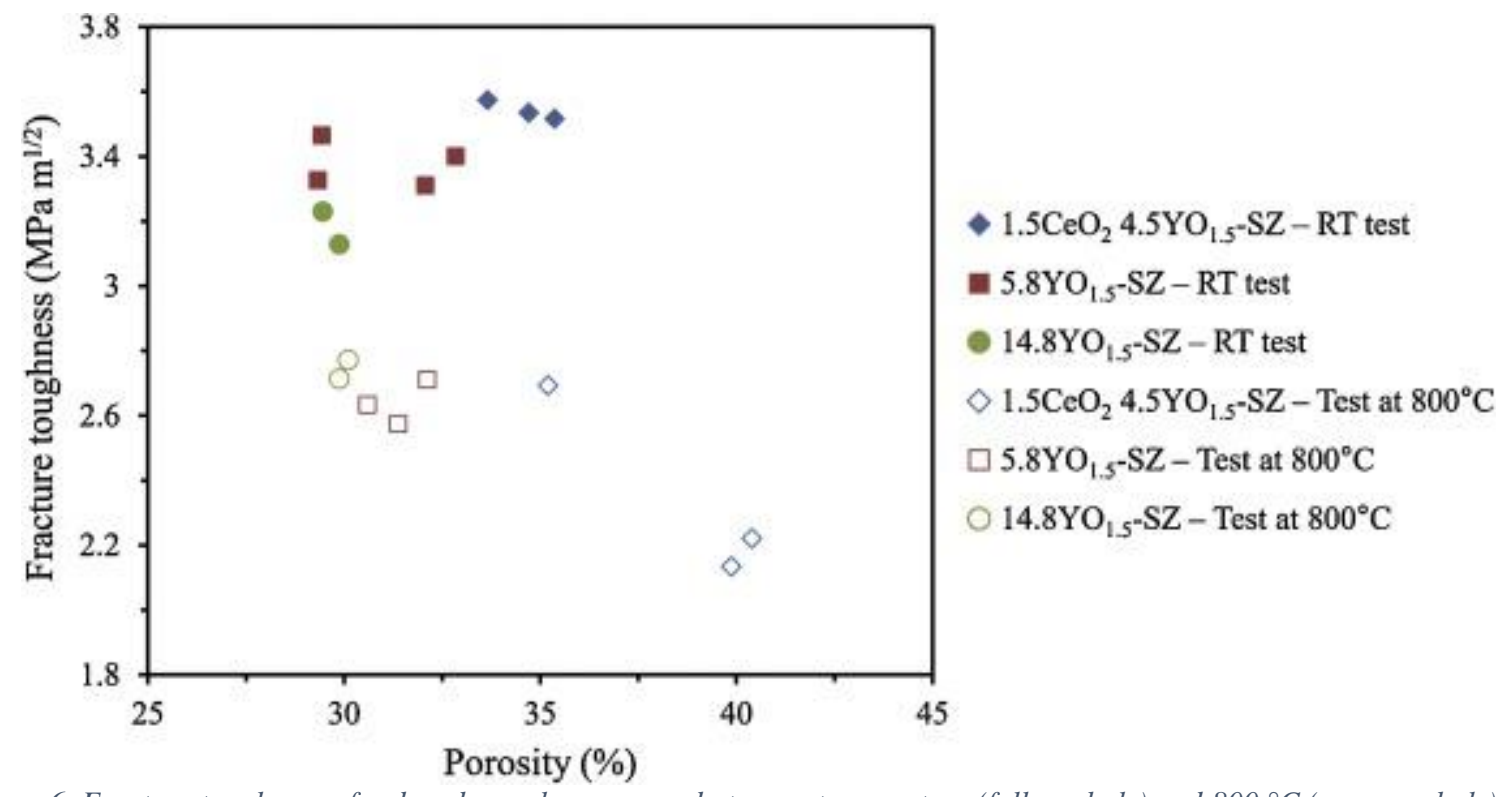

Figure 6. Fracture toughness of reduced samples measured at room temperature (full symbols) and $800{ }^{\circ} \mathrm{C}$ (open symbols). The uncertainty of the measurements is in the range of.3-5\%. 
At $800{ }^{\circ} \mathrm{C}$, the fracture toughness of the supports drops considerably, yet tetragonal- and cubic zirconia-based supports have rather similar fracture toughness. Moreover, considering the studied range of porosities, it is seen that in a reduced state the toughness decreases significantly by increasing porosity.

\subsection{Fractured surfaces}

Typical Raman spectra of the surface and fractured surface of $\mathrm{NiO}-5.8 \mathrm{YO}_{1.5}$-SZ support, fractured at room temperature are shown in Figure 10a and b (Appendix A. Supplementary data), respectively. The Raman spectra of the surface of the sample were taken at a place far from the propagated crack. The spectra were recorded along a $20 \mu \mathrm{m}$ line with $2 \mu \mathrm{m}$ spans. The characteristic peaks of the monoclinic phase, i.e. at the Raman shifts of 180 and $192 \mathrm{~cm}^{-1}$ are seen in the spectra of the fractured surface, while no monoclinic phase is detected on the surface of the sample (consistent with the XRD result of the as-sintered $\mathrm{NiO}-5.8 \mathrm{YO}_{1.5}-\mathrm{SZ}$ support,

Table 2).

Moreover, at the fracture surface the intensity of the monoclinic peaks changes at different points. This can be explained by the presence of pores and $\mathrm{NiO}$ grains in the studied intervals $(2 \mu \mathrm{m})$, as observed by the SEM images of the samples (Figure 2).

The average amount of monoclinic phase in the 10 studied points was calculated to be ca. $4 \%$. In contrast, Raman spectra of the fractured surface of the $\mathrm{NiO}-5.8 \mathrm{YO}_{1.5}-\mathrm{SZ}$ support fractured at 800 ${ }^{\circ} \mathrm{C}$ showed no monoclinic phase. Thus, the tetragonal to monoclinic phase transformation is occurring while fracturing at room temperature but not (or hardly at all) at $800{ }^{\circ} \mathrm{C}$.

Figure 11 (Appendix A. Supplementary data) presents the typical Raman spectra of NiO-4.9YO 1.5- $^{-}$ SZ support, taken at a spot far from the propagated crack (Figure 11a), and from the fractured surfaces of samples fractured at room temperature (Figure $11 \mathrm{~b}$ ) and at $800{ }^{\circ} \mathrm{C}$ (Figure $11 \mathrm{c}$ ). The average amount of the monoclinic phase on the surface of sample was calculated to be $\approx 2.5 \%$ (consistent with the monoclinic content of the as-sintered $\mathrm{NiO}-4.9 \mathrm{YO}_{1.5}-\mathrm{SZ}$ measured by XRD, i.e. $\approx 2 \%$,

Table 2). For fractured surfaces, a monoclinic content of approximately $9 \%$ and $5 \%$ was calculated for samples fractured at room temperature and $800{ }^{\circ} \mathrm{C}$, respectively. Deducting the amount of monoclinic phase, formed already upon sintering, the Raman results indicate that compared to the $\mathrm{NiO}-5.8 \mathrm{YO}_{1.5}-\mathrm{SZ}$ the tetragonal to monoclinic phase transformation occurs to a higher degree in the $\mathrm{NiO}-4.9 \mathrm{YO}_{1.5}-\mathrm{SZ}$. Yet, the extent of transformation while fracturing at $800{ }^{\circ} \mathrm{C}$ is small, although higher than in the $\mathrm{NiO}-5.8 \mathrm{YO}_{1.5}-\mathrm{SZ}$.

The results of Raman spectroscopy analysis is summarized in Table 3.

Table 3. The monoclinic phase fraction on the surface and fractured surfaces of $\mathrm{NiO}-5.8 \mathrm{YO}_{1.5-\mathrm{SZ}}$ and $\mathrm{NiO}-4.9 \mathrm{YO}_{1.5}-\mathrm{SZ}$ supports, detected using Raman spectroscopy.

\begin{tabular}{|c|c|c|c|}
\hline Sample notation & $\begin{array}{l}\text { Monoclinic content } \\
\text { on the surface }(\%)\end{array}$ & $\begin{array}{l}\text { Monoclinic content on the } \\
\text { fractured surface at RT }(\%)\end{array}$ & $\begin{array}{l}\text { Monoclinic content on the } \\
\text { fractured surface at } 800^{\circ} \mathrm{C}(\%)\end{array}$ \\
\hline $\begin{array}{c}\mathrm{NiO}-5.8 \mathrm{YO}_{1.5-} \\
\text { SZ }\end{array}$ & 0 & 4 & 0 \\
\hline $\begin{array}{c}\mathrm{NiO}-4.9 \mathrm{YO}_{1.5^{-}} \\
\mathrm{SZ}\end{array}$ & 2.5 & 9 & 5 \\
\hline
\end{tabular}


It is worth mentioning that detection and quantification of the monoclinic phase on fractured surfaces of porous, fine-grained zirconia ceramics (as it is the case in this study) using Raman spectroscopy is quite difficult [45]. This is due to the small transformation zone (which can be as small as $1 \mu \mathrm{m}$ in $3 \mathrm{YSZ}$ with average grain size of $\approx 300 \mathrm{~nm}$ [46]) as well as the porous structure of the ceramic. Nevertheless, the Raman spectroscopy results in this study confirm the transformation toughening as a toughening mechanism in the tetragonal zirconia based SOC supports. In this context, the measured higher toughness of $\mathrm{NiO}-4.9 \mathrm{YO}_{1.5}-\mathrm{SZ}$ and $\mathrm{NiO}-1.5 \mathrm{CeO}_{2}$ 4.5 $\mathrm{YO}_{1.5}-\mathrm{SZ}$ supports is a consequence of the higher transformability of the zirconia phase, resulting in a higher toughening.

At $800{ }^{\circ} \mathrm{C}$ the extent of observed transformation decreases markedly, impairing the fracture toughness at high temperatures (Figure 4). Nevertheless, the fracture toughness of tetragonal zirconia-based samples at $800{ }^{\circ} \mathrm{C}$ is still markedly higher than that of the NiO-14.8YO $\mathrm{YO}_{1.5} \mathrm{SZ}$. This indicates that the transformation toughening is probably not the only toughening mechanism in the tetragonal zirconia-based samples.

\subsection{Hydrothermal degradation (HTD and LTD) studies}

Figure 7a shows the amount of retained tetragonal phase in the tetragonal zirconia-based supports, as sintered (Table 1) and after HTD experiment (i.e. aging in $3 \% \mathrm{H}_{2} \mathrm{O} / 4 \% \mathrm{H}_{2} / \mathrm{N}_{2}$ at $800{ }^{\circ} \mathrm{C}$ for 200 and $850 \mathrm{~h}$ ). The monoclinic phase content in the Ce-Y co-doped samples does not change considerably after the HTD experiment. In the $4.9 \mathrm{YO}_{1.5}$-SZ based support $8 \%$ monoclinic phase is formed after $200 \mathrm{~h}$ aging, while it increases to $35 \%$ after $850 \mathrm{~h}$. Also, in the $5.8 \mathrm{YO}_{1.5}$-SZ based sample a minor phase transformation $(\approx 2 \%)$ was observed. It is worth mentioning that in the $5.8 \mathrm{YO}_{1.5}-\mathrm{SZ}$ based supports studied in this work formation of minor monoclinic phase in asreduced samples had also been observed in some batches. This can be due to the possible differences in the grain sizes of samples, resulting from the differences in ceramic processing.

(a)

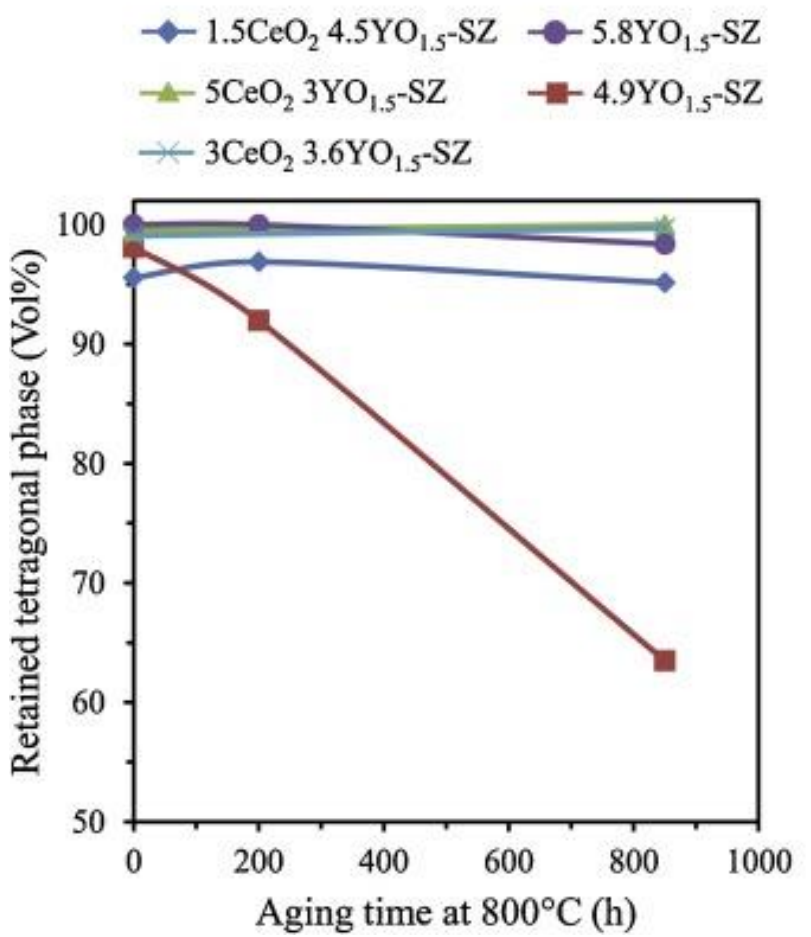

(b)
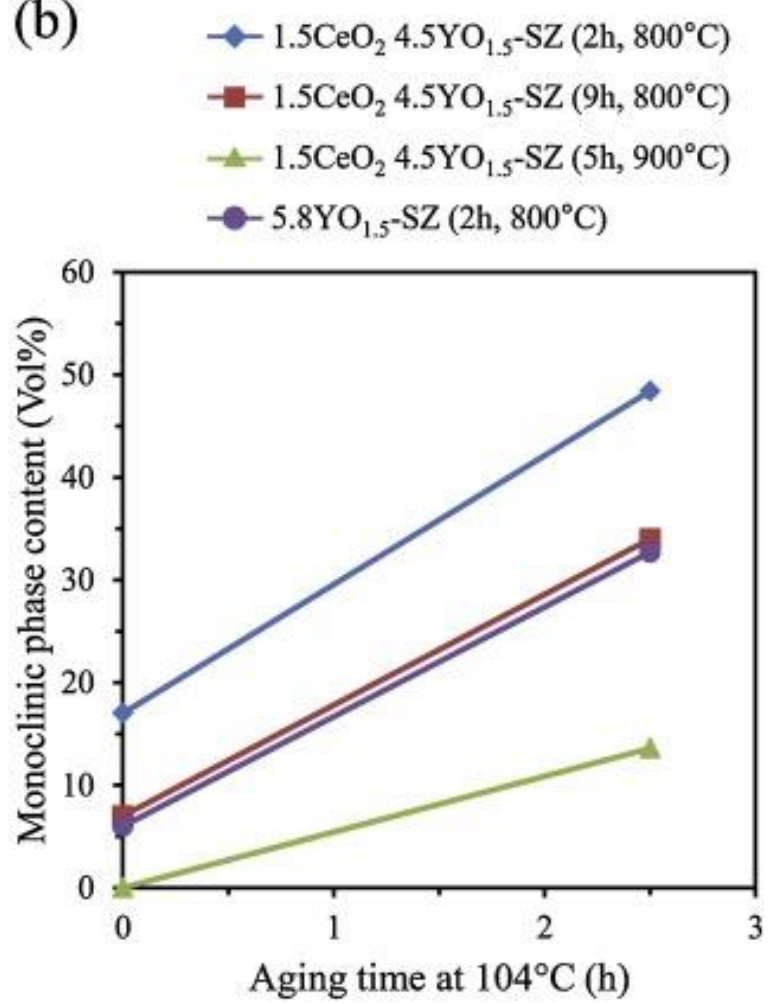

Figure 7. (a) Amount of the tetragonal phase retained in as-sintered samples (the data at time zero) and after HTD experiment in $3 \% \mathrm{H}_{2} \mathrm{O} / 4 \% \mathrm{H}_{2} / \mathrm{N}_{2}$ at $800{ }^{\circ} \mathrm{C}$ for 250 and $850 \mathrm{~h}$. (b) Amount of the monoclinic phase formed in $\mathrm{Ni}-1.5 \mathrm{CeO}_{2} 4.5 \mathrm{YO}_{1.5-}-\mathrm{SZ}_{\text {and }} \mathrm{Ni}-$ 
The lower stability of the tetragonal phase in $4.9 \mathrm{YO}_{1.5}-\mathrm{SZ}$ based support can be attributed to its low amount of stabilizer; the $5.8 \mathrm{YO}_{1.5}$-SZ based sample, with a higher amount of stabilizer, has higher resistance to HTD.

As reported in our previous work [30], the effect of $\mathrm{CeO}_{2}$ in stabilizing the tetragonal zirconia is approximately half of $\mathrm{YO}_{1.5}$. This ratio will be applicable to the as-sintered $\mathrm{NiO}-\mathrm{SZ}$ supports. Hence, in the oxidized form, the stabilizing effect of dopants in the Ce-Y co-doped compounds can be considered to be very close to $4.9 \mathrm{YO}_{1.5}-\mathrm{SZ}$ (for instance, the stabilizing efficiency in zirconia co-doped with $1.5 \mathrm{CeO}_{2}$ and $4.5 \mathrm{YO}_{1.5}$ is approximately equal to $5.25 \mathrm{YO}_{1.5}$ ). Nevertheless, unlike the 4.9 $\mathrm{YO}_{1.5}-\mathrm{SZ}$ compound, the tetragonal phase in reduced $\mathrm{Ce}-\mathrm{Y}$ co-doped supports was highly stable, manifested in their excellent HTD resistance (Figure 7a). This could be due to an additional stabilizing effect of $\mathrm{Ce}^{3+}$ formed upon reduction in the co-doped compounds. To evaluate this hypothesis, the $1.5 \mathrm{CeO}_{2} 4.5 \mathrm{YO}_{1.5}$-SZ-based support was reduced at different conditions and its LTD behavior was investigated and compared to that of 5.8 $\mathrm{YO}_{1.5}$-SZbased support (Figure 7b).

In Figure $7 b$, the data at time zero shows the amount of the monoclinic phase formed upon reduction (i.e. the monoclinic content in as-sintered form is deducted from that of the as-reduced samples). As seen, in the co-doped compound increasing the time and temperature of reduction decreases the amount of monoclinic phase formed in the as-reduced support. By reducing the sample at $900{ }^{\circ} \mathrm{C}$ for $5 \mathrm{~h}$, no monoclinic phase is formed. Interestingly, increasing the reduction time and temperature also improves the LTD resistance of the as-reduced samples. The sample reduced for $5 \mathrm{~h}$ at $900{ }^{\circ} \mathrm{C}$ shows the highest resistance to hydrothermal degradation, markedly higher than the 5.8 $\mathrm{YO}_{1.5}$-SZ based support despite the latter having a larger amount of stabilizing agent (5.8 mol\% yttrium).

The LTD experiment confirms the effect of reduction profile on the stability of tetragonal phase in the co-doped zirconia-based supports. In addition, it is found that tetragonal zirconia-based supports are highly susceptible to LTD, a phenomenon that can negatively affect the structural reliability of the cells.

Figure 8 presents the room temperature fracture toughness of $1.5 \mathrm{CeO}_{2} 4.5 \mathrm{YO}_{1.5} \mathrm{SZ}$ and $5.8 \mathrm{YO}_{1.5^{-}}$ SZ based supports, as-reduced and after the aging at $800{ }^{\circ} \mathrm{C}$ for $850 \mathrm{~h}$. The samples had approximately similar porosities $(\approx 35 \%)$. The fracture toughness of both samples drops after the aging, while the decrease in the fracture toughness of the yttria doped material is higher than the Ce-Y co-doped support. The latter has approximately $18 \%$ higher fracture toughness after the long term aging. Finding the reason behind the mechanical degradation of the zirconia based supports requires further investigations. However, it is concluded that co-doping can improve the degradation resistance of the tetragonal zirconia-based SOCs supports. 


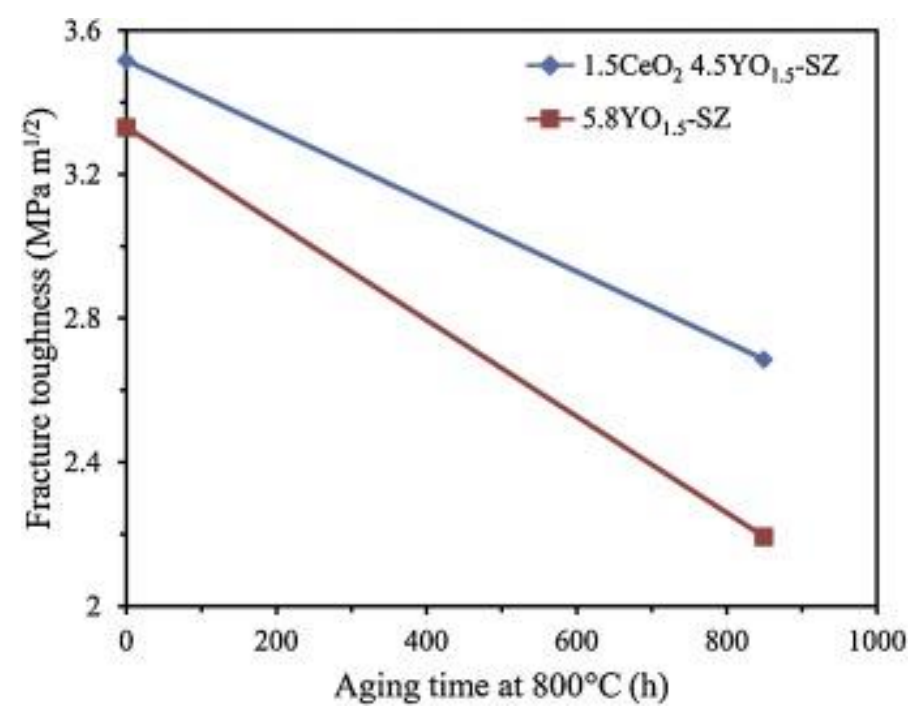

Figure 8. Room temperature fracture toughness of 1.5 $\mathrm{CeO}_{2} 4.5 \mathrm{YO}_{1.5-\mathrm{SZ}}$ and 5.8YO $\mathrm{Y}_{1.5}$-SZ based supports, as-reduced (the data at time zero) and after aging in $3 \% \mathrm{H}_{2} \mathrm{O} / 4 \% \mathrm{H}_{2} / \mathrm{N}_{2}$ at $800{ }^{\circ} \mathrm{C}$ for $850 \mathrm{~h}$.

\section{Discussion}

\subsection{Effects of NiO}

Minor amounts of the monoclinic phase $(\leq 5 \%)$ were found in some pristine NiO-SZ samples. The transformation boundary diagrams developed in our previous work [30], predicts that the amount of stabilizer(s) in all the compounds studied here should be high enough to retain the tetragonal phase upon cooling from the applied sintering temperatures. This was validated for the plain zirconia samples $\left(4.9 \mathrm{YO}_{1.5}-\mathrm{SZ}\right.$ and $\left.1.5 \mathrm{CeO}_{2} \quad 4.5 \mathrm{YO}_{1.5}-\mathrm{SZ}\right)$; these materials were fully tetragonal. Also, the average grain sizes of the zirconia phase in the plain and composite states are rather similar. Therefore, the formation of minor amounts of the monoclinic phase in the composite systems reported on here is most likely due to the presence of the second phase, i.e. NiO, in the matrix.

$\mathrm{NiO}$ has a low solubility in yttria doped stabilized zirconia, typically below 5 mol\% after firing at elevated temperatures (above $1500{ }^{\circ} \mathrm{C}$ ) [47-49]. It is known that the presence of $\mathrm{NiO}$ can increase the stability of the cubic phase [47-50]. The effect of $\mathrm{NiO}$ grains on the phase stability of the tetragonal phase in a tetragonal zirconia ceramic is not well studied, though it has been reported that doped $\mathrm{NiO}$ cannot be solely a stabilizing agent for the tetragonal phase [51].

Delaforce and co-workers [52] investigated the effects of a NiO layer screen printed on a dense 3 mol\% yttria stabilized zirconia on the phase composition of the substrate after firing at temperatures between $1350-1550{ }^{\circ} \mathrm{C}$. The NiO coated $3 \mathrm{YSZ}$ sample contained tetragonal and a small amount of cubic phase after heat treatment at $1350{ }^{\circ} \mathrm{C}$, similarly to the $3 \mathrm{YSZ}$ sample without $\mathrm{NiO}$. By increasing the heat-treatment temperature and dwell time, especially at temperatures above $1500{ }^{\circ} \mathrm{C}$, the amount of tetragonal phase decreased and more cubic and monoclinic phase were formed, while the phase composition remained practically unchanged in the 3 YSZ sample without $\mathrm{NiO}$. They concluded that at all temperatures the presence of $\mathrm{NiO}$ facilitates the growth of the tetragonal grains, which in turn facilitates the formation of the monoclinic phase, as more grains reach the critical size for the tetragonal to monoclinic phase transformation. 
It is important to note that the NiO-SZ supports investigated in this work are a mixture of $\mathrm{NiO}$ and tetragonal zirconia grains, making it different from the layered structure studied by Delaforce and co-workers [52]. Moreover, considering the heat-treatment temperature applied in this work, it is unlikely that the formation of monoclinic phase can be attributed to the higher grain growth of the tetragonal grains or dissolution of $\mathrm{NiO}$. The observed destabilizing effect of $\mathrm{NiO}$ requires a different explanation.

In a composite made of tetragonal grains and a second phase, two important parameters could affect the stability of the tetragonal grains, namely the coefficient of thermal expansion (CTE) and the Young's modulus of the second phase. A lower CTE of the second phase than that for zirconia results in a tensile residual stress in the zirconia phase, which facilitates the tetragonal to monoclinic phase transformation. Furthermore, the tetragonal grains can more readily undergo the tetragonal to monoclinic phase transformation if the surrounding matrix has a lower Young's modulus. This is the reason why the phase transformation is observed to be more pronounced in a porous structure [53]. The CTE and Young's modulus of NiO and YSZ are presented in Table 4. As can be seen, NiO has a higher CTE than the YSZ, and a lower Young's modulus. As a result, compressive residual stress will form in the zirconia phase upon cooling from the sintering step, when surrounded by $\mathrm{NiO}$ grains. A hypothesis for the observed reduced phase stability could be that the destabilizing effect of the low Young's modulus of the neighboring matrix surpasses the stabilizing effect of the compressive residual stress.

Table 4. Coefficient of thermal expansion (CTE) and young's modulus of NiO and stabilized zirconia.

\begin{tabular}{|c|c|c|}
\hline Material & CTE $\left(10^{-6} \mathrm{~K}^{-1}\right)$ & $\mathbf{E}(\mathbf{G P a})$ \\
\hline NiO & $11-16^{\mathrm{a}}\left(25-1000^{\circ} \mathrm{C}\right)[54]$ & $96^{\mathrm{b}}[55]$ \\
\hline $3 Y S Z\left(5.8 Y O_{1.5}-S Z\right)$ & $8.5-11\left(25-600{ }^{\circ} \mathrm{C}\right)[56]$ & 216 [57] \\
\hline $8 Y S Z\left(14.8 Y O_{1.5-S Z}\right)$ & $9-12\left(25-1000^{\circ} \mathrm{C}\right)[54]$ & $220[58]$ \\
\hline
\end{tabular}

${ }^{a}$ Showing a max of $18.5 \cdot 10^{-6} \mathrm{~K}^{-1}$ at $250{ }^{\circ} \mathrm{C}$.

${ }^{\mathrm{b}}$ Showing a max of $245 \mathrm{GPa}$ at $250{ }^{\circ} \mathrm{C}$.

For comparison, alumina-tetragonal zirconia composites can be considered. Alumina has a lower CTE and higher Young's modulus than zirconia. In this case the presence of alumina increases the stability of the tetragonal phase [20], indicating that the stabilizing effect of a higher Young's modulus dominates over the destabilizing effect of tensile residual stresses resulting from a lower CTE.

One can thus conclude that in $\mathrm{NiO}-5.8 \mathrm{YO}_{1.5}-\mathrm{SZ}$ supports the stabilizer content is high enough to stabilize the tetragonal phase even in the presence of the NiO. Nonetheless, the new compounds studied in this work contain lower amount of stabilizer(s), thus a small monoclinic fraction is formed in the corresponding NiO-SZ composites. The destabilizing effect of the $\mathrm{NiO}$ grains in the NiO-SZ composite possibly also influences the extent of the transformation toughening. The relatively small amount of the monoclinic phase observed at surfaces fractured at $800{ }^{\circ} \mathrm{C}$, can also be a consequence of the destabilizing effect of $\mathrm{NiO}$ (besides being an effect of the high porosity).

\subsection{Effect of temperature and grain size on the fracture toughness}

The fracture toughness of the tetragonal zirconia-based supports in the oxidized form was significantly higher than that of their cubic zirconia-based counterpart. The difference was highest at room temperature but persisted, to a lesser degree at $800{ }^{\circ} \mathrm{C}$. Pećanac and co-workers [18] observed the same trend in their investigations of the tetragonal and cubic zirconia based supports. Fracture toughness of the NiO-3YSZ supports at room temperature was $3.05 \mathrm{MPa} \mathrm{m}{ }^{1 / 2}$, significantly higher than that of the $\mathrm{NiO}-8 \mathrm{YSZ}$ supports, i.e. $1.76 \mathrm{MPa} \mathrm{m}^{1 / 2}$. The toughness of 
NiO-3YSZ decreased to $2.64 \mathrm{MPa} \mathrm{m}{ }^{1 / 2}$ at $800{ }^{\circ} \mathrm{C}$, while in the NiO-8YSZ support remained almost similar (1.93 $\left.\mathrm{MPa} \mathrm{m}^{1 / 2}\right)$. The higher values of the $3 \mathrm{YSZ}$ based support at room temperature and (to a lower extent) at $800{ }^{\circ} \mathrm{C}$ were attributed to the effect of the transformation toughening (which decreases at $800{ }^{\circ} \mathrm{C}$ ). The authors did not study the crystalline phase composition of the fracture surfaces and the grain sizes of the samples were not reported.

Generally, the driving force for the tetragonal to monoclinic phase transformation in transformable tetragonal zirconia-based ceramics decreases with increasing temperature, as the tetragonal phase becomes thermodynamically more stable. Consequently, the transformation toughening becomes less effective at higher temperatures. For a $3 \mathrm{~mol} \%$ yttria doped tetragonal zirconia single crystals, for instance, it has been reported that the stress induced tetragonal to monoclinic phase transformation does not occur above $900{ }^{\circ} \mathrm{C}$ [59].

Theunissen and co-workers [60] reported the variation in fracture toughness of $2.5 \mathrm{~mol} \%$ yttria doped zirconia samples with grain sizes of 750, 300 and $180 \mathrm{~nm}$ from room temperature to 800 ${ }^{\circ} \mathrm{C}$. Although all the samples had comparable fracture toughness at room temperature, the monoclinic phase could not be detected in fractured surfaces of the samples with grain sizes of 180 and $300 \mathrm{~nm}$, and the drop in fracture toughness with increasing temperature was found to be most substantial in sample with the largest average grain size $(750 \mathrm{~nm})$. The authors suggested that the higher toughness observed for the fine-grained samples is a consequence of crack deflection and not transformation toughening; hence the reduced effect of temperature.

The effect of grain size on the fracture toughness of zirconia ceramics is well studied. Trunec [61] investigated the fracture toughness of $3 \mathrm{~mol} \%$ yttria doped zirconia having different grain sizes, ranging from 0.19 to $2.15 \mu \mathrm{m}$. The toughness of samples with grain sizes up to $0.4 \mu \mathrm{m}$ was rather similar, while an increase in toughness was observed by further increase in the grain size. The same trend was reported by Tsukuma and Shimada [62] for ceria doped tetragonal zirconia, where samples with larger grain sizes possess higher fracture toughness despite having similar stabilizer content. This increase in the fracture toughness of the transformable tetragonal zirconia ceramics can be explained by the higher transformability of the larger grains because such grains are closer to the critical grain size for the tetragonal to monoclinic phase transformation and hence provide more toughening on application of a stress. For $8 \mathrm{YSZ}$ zirconia on the other hand decreasing fracture toughness by increasing grain size has been reported $[63,64]$.

Considering the average grain size of the tetragonal and cubic zirconia-based samples studied in this work, along with the Raman spectroscopy results, it can be concluded that the higher toughness in the tetragonal zirconia samples is due to the transformation toughening effect and their smaller grain size in tandem. However, at high temperatures the transformation toughening decreases dramatically and we believe that the higher toughness of the tetragonal zirconia as compared to the cubic samples is predominantly a consequence of the smaller grain sizes in the tetragonal samples. In this context, the higher fracture toughness of $1.5 \mathrm{CeO}_{2} 4.5 \mathrm{YO}_{1.5}-\mathrm{SZ}$ compared to 5.8 $\mathrm{YO}_{1.5} \mathrm{SZ}$, while both samples have rather similar grain size distribution, can be ascribed to a higher transformability of the former, following from its lower content of stabilizing agents. There is no change in the toughness of $\mathrm{NiO}-14.8 \mathrm{YO}_{1.5} \mathrm{SZ}$ supports between room and high temperatures, since the transformation toughening does not occur in cubic zirconia.

As mentioned earlier, with conventional sintering the grain size of sintered $14.8 \mathrm{YO}_{1.5}-\mathrm{SZ}$ is (typically) several times that of $5.8 \mathrm{YO}_{1.5}$-SZ ceramics. This suggests that the cubic zirconia based supports studied by Pećanac and co-workers [18] had larger grain size than the tetragonal zirconia based one. The higher fracture toughness of the NiO-3YSZ (NiO-5.8 $\left.\mathrm{YO}_{1.5}-\mathrm{SZ}\right)$ support compared 
to the $\mathrm{NiO}-8 \mathrm{YSZ}\left(\mathrm{NiO}-14.8 \mathrm{YO}_{1.5}-\mathrm{SZ}\right)$ one at $800{ }^{\circ} \mathrm{C}$ reported in [18] is thus likely an effect of smaller grains than an effect of transformation toughening.

\subsection{Effect of reduction on the fracture toughness}

The significantly higher room temperature fracture toughness of the reduced samples compared to the samples in the oxidized form shows that presence of highly ductile Ni phase overshadows the effect of the higher porosity. The toughening effect from the plastic deformation of the Ni-phase in Ni-SZ SOC supports is well-known $[18,65]$. Moreover, the high ductility of Ni resulted in comparable fracture toughness of tetragonal and cubic zirconia based supports (Figure 6), in contrast to the differences observed among the samples in the oxidized state (see Figure 3).

On the other hand, the fracture toughness of the reduced samples decreased dramatically when heated to $800{ }^{\circ} \mathrm{C}$, as is also observed in $[18,65]$. This observation can be explained by the lower stiffness and yield stress of $\mathrm{Ni}$ at $800{ }^{\circ} \mathrm{C}$. Radovic and co-workers [65] reported that the number of deformed Ni ligaments close to the crack tip decrease in Ni-SZ samples fractured at higher temperatures, why crack bridging by $\mathrm{Ni}$ ligaments became less effective as a toughening mechanism. Creep of the Ni would decrease the fracture toughness even further, but this cannot be effective in the relatively fast fracturing in the double torsion test (i.e. in the order of seconds). It could be however relevant for the slow crack growth driven by stresses from a thermal gradient.

It is well known that when taking into account the fracture toughness of materials, the measured values are in particular dependent on the measurement technique, testing conditions and sample and notch geometries. Goutianos and co-workers [16] measured the room temperature fracture toughness of NiO-3YSZ samples with a porosity of ca. $15 \%$ using double cantilever beam test. The average fracture toughness for crack initiation was obtained to be $1.97 \mathrm{MPa} \mathrm{m}^{1 / 2}$ when testing samples with a sharp notch, and $2.19 \mathrm{MPa} \mathrm{m}^{1 / 2}$ for samples with a micro-notch. The latter is in a good agreement with the toughness of NiO-3YSZ measured in the current study using the double torsion method (i.e. $2.4 \mathrm{MPa} \mathrm{m}^{1 / 2}$ at the porosity of $15 \%$ ).

Nonetheless, comparing the fracture toughness values of $\mathrm{Ni}(\mathrm{O})-3 \mathrm{YSZ}$ and $\mathrm{Ni}(\mathrm{O})-8 \mathrm{YSZ}$ samples measured in the present work with those reported by Pećanac and co-workers [18] an inconsistency is observed, although the samples are produced using the same recipes and powders, and the same testing technique was used. The measured values in [18] are $10-22 \%$ and $15-34 \%$ higher in the oxidized and reduced states, respectively. For instance, Pećanac and co-workers [18] reported the fracture toughness of NiO-3YSZ with porosity of $13 \%$ to be $3.05 \mathrm{MPa} \mathrm{m}^{1 / 2}$. This is $22 \%$ higher than the value obtained in our work (i.e. $2.5 \mathrm{MPa} \mathrm{m}^{1 / 2}$, see Figure 3).

To clarify the reason behind this discrepancy we measured the fracture toughness of 3 YSZ based samples from the same batch (sister cells), at IEK-2 Forschungszentrum Jülich and at MATEIS INSA-Lyon. The results at the latter were quite consistent with our values obtained at DTU Energy. We therefore believe that the fracture toughness values reported in [18] are slightly overestimated, probably originating from the high preload in their testing procedure, which could bias the measured loads.

\subsection{Effects of reduction step and reduction of $\mathrm{Ce}^{4+}\left(\right.$ to $\left.\mathrm{Ce}^{3+}\right)$ on the stability of tetragonal phase}

The crystalline phase analysis of as-reduced Ni-SZ samples at room temperature (Figure 7b) showed that the monoclinic zirconia can be formed during the reduction step. Formation of this monoclinic phase can be explained by the effects of large porosity generated upon reduction. Compared to a dense zirconia, the tetragonal grains in a porous structure can easier transform to 
the monoclinic phase [30]. The reduction step increases the porosity of ceramic, hence facilitates the tetragonal to monoclinic phase transformation to occur upon cooling from the reduction temperature. Here, the amount of stabilizer will play a major role. For instance, in samples reduced at $800{ }^{\circ} \mathrm{C}$ for $2 \mathrm{~h}$, the amount of monoclinic phase found in as-reduced $5.8 \mathrm{YO}_{1.5}$-SZ based support was around $6 \%$, significantly lower than that in as-reduced $1.5 \mathrm{CeO}_{2} 4.5 \mathrm{YO}_{1.5}-\mathrm{SZ}$ based support $(\approx 17 \%)$. The difference can be explained by the higher stabilizer concentration of the former. Increasing the reduction time and temperature in the co-doped zirconia-based support decreased the monoclinic phase content in the as-reduced samples. It also improved their resistance to LTD.

The observed improved stability of the tetragonal phase in the co-doped zirconia-based sample by increasing the time and temperature of reduction, manifested in the enhanced resistance to HTD, LTD and phase transformation upon reduction, can be attributed to an increasing stabilizing effect of $\mathrm{Ce}^{3+}$ than $\mathrm{Ce}^{4+}$, that is boosted by increasing the extent of reduced $\mathrm{Ce}$.

Studies on the phase stability of Ce-doped zirconia shows that heat treatment in reducing atmosphere at high temperatures $\left(>1200^{\circ} \mathrm{C}\right)$ can result in the formation of a second phase $[66,67]$, probably as a result of the reduction of $\mathrm{Ce}^{4+}$ and $\mathrm{Zr}^{4+}$ to $\mathrm{Ce}^{3+}$ and $\mathrm{Zr}^{3+}$, respectively [66]. It also decreases the stability of the tetragonal phase retained at room temperature and may even result in the formation of the monoclinic phase upon the subsequent cooling from the high treatment temperature. This is ascribed to the depletion of stabilizer in the tetragonal zirconia matrix to levels lower than required for retaining the tetragonal phase to room temperature [67-70]. At lower reduction temperatures $\left(<1000{ }^{\circ} \mathrm{C}\right)$ no formation of an extra phase is reported, as here $\mathrm{Zr}^{4+}$ to $\mathrm{Zr}^{3+}$ reduction does not occur, nor does segregation of $\mathrm{Ce}^{3+}$ to the grain boundaries, and an increase in the stability of the tetragonal phase is actually observed [66,71]. To explain the increased stability, it is useful to consider in more details the stabilizing mechanisms of cerium and yttrium cations in doped zirconia system:

The stabilization of the tetragonal phase using a stabilizer is in fact achieved by relieving the oxygen "overcrowding" around $\mathrm{Zr}^{4+}$ cations. The oversized $\mathrm{Y}^{3+}$ cations reduce the oxygen overcrowding by both introducing $\mathrm{Zr}$-associated oxygen ion vacancies and through the dilatation of the cation network. Doping tetravalent cations however, does not produce any oxygen vacancy. Accordingly, the stabilizing effect of the oversized $\mathrm{Ce}^{4+}$ cations is only through the dilatation of cation network $[21,22,72]$, an explanation for why the effect of $\mathrm{Y}^{3+}$ is approximately the double of that for $\mathrm{Ce}^{4+}$, because no oxygen vacancies are generated by doping of tetravalent cations.

The valence change of $\mathrm{Ce}^{4+}$ to $\mathrm{Ce}^{3+}$ at the reduction temperatures studied in this work introduces oxygen ion vacancies. As a result, the oversized trivalent $\mathrm{Ce}^{3+}$ (with ionic radios of $1.07 \AA$ as compared to $\mathrm{Ce}^{4+}: 0.94 \AA$ and $\mathrm{Zr}^{4+}: 0.86 \AA$ ) provides a more efficient stabilization by both mechanisms. Obviously, the increased stabilizing effect is dependent on the extent of reduction of $\mathrm{Ce}^{4+}$ cations. Increasing the temperature of the reducing atmosphere and the reduction duration will increase the extent of the reduction. As observed in the LTD study of the reduced $1.5 \mathrm{CeO}_{2}$ $4.5 \mathrm{YO}_{1.5}-\mathrm{SZ}$ based supports (Figure $7 \mathrm{~b}$ ) increasing the reduction time and temperature leads to an enhanced resistance to LTD. This can be explained by the higher degree of reduction of $\mathrm{CeO}_{2}$, therefore increasing the stability of the tetragonal phase. A stabilizing effect of $\mathrm{Ce}^{3+}$ resulting from the reduction from $\mathrm{Ce}^{4+}$ in $\mathrm{Sc}-\mathrm{Ce}$ co-doped tetragonal zirconia samples has also been reported by Kubrin and co-workers [73].

The aging studies (LTD and HTD) carried out in this work indicate that tetragonal stabilized zirconia-based supports are highly susceptible to hydrothermal degradation. It is crucial for the SOC technologies that the tetragonal phase in the supports is stable for thousands of hours during operation at high temperatures $\left(>700{ }^{\circ} \mathrm{C}\right.$, where it can result in HTD) and through thermal cycles 
(where LTD can occur). The present work shows that lowering the yttria content from $5.8 \mathrm{~mol} \%$ yttrium to $4.9 \mathrm{~mol} \%$ negatively influences the HTD resistance of the tetragonal phase, hence is not a reliable approach for improving the fracture toughness of the supports. Alternatively, lowering the stabilizer concentration to obtain enhanced toughness should be considered with a Ce-Y codoping approach. This is because the $\mathrm{Ce}^{3+}$ generated during reduction will provide additional stabilizing effect in the reduced state, making up the lower stabilizer level primarily present in the pristine support. This can mitigate the hydrothermal degradation issues (LTD and HTD). Nevertheless, a proper reduction profile is necessary to generate enough amounts of $\mathrm{Ce}^{3+}$, which for $1.5 \mathrm{CeO}_{2} 4.5 \mathrm{YO}_{1.5}-\mathrm{SZ}$ based support, was found to be $5 \mathrm{~h}$ at $900{ }^{\circ} \mathrm{C}$ in $4 \% \mathrm{H}_{2} / \mathrm{N}_{2}$.

\section{$\underline{\text { 5. Conclusions }}$}

In this work, porous $\mathrm{Ni}(\mathrm{O})-\mathrm{SZ}$ composites, intended for use as fuel electrode supports, with six different stabilized zirconia compounds, were prepared and characterized. The results of this study can be summarized as follows:

- Lowering the stabilizer content (below the $5.8 \mathrm{~mol} \%$ yttrium used in the state-of-the-art 3 YSZ based supports) can improve the fracture toughness of supports in the oxidized state by increasing the transformability of the tetragonal zirconia, consequently providing more transformation toughening. The transformation toughening effect, however, decreases drastically at $800{ }^{\circ} \mathrm{C}$. Compared to the state-of-the-art NiO-5.8YO ${ }_{1.5}-\mathrm{SZ}$ support, the $\mathrm{NiO}$ $1.5 \mathrm{CeO}_{2} 4.5 \mathrm{YO}_{1.5}-\mathrm{SZ}$ support possesses improved toughness with as much as 30 and $10 \%$ at both room temperature and $800{ }^{\circ} \mathrm{C}$, respectively.

- In the reduced state, the tetragonal and cubic zirconia-based supports exhibit comparable fracture toughness at room temperature and $800{ }^{\circ} \mathrm{C}$, because the toughness is primarily related to the ductility of $\mathrm{Ni}$.

- The higher fracture toughness of the tetragonal zirconia-based supports compared to their cubic zirconia-based counterparts in the oxidized form (e.g. $\approx 70 \%$ higher at the porosity of $15 \%$ ) was concluded to be partly due to the transformation toughening effect and partly due to a finer grained microstructure.

- Presence of $\mathrm{NiO}$ in a matrix of $\mathrm{NiO}$ and tetragonal zirconia grains was found to have destabilizing effect on the tetragonal phase. Hence and by considering the well-known negative effect of porosity on the stability of the tetragonal zirconia, both presence of porosity and $\mathrm{NiO}$ contribute to increasing the extent of the transformation toughening in $\mathrm{NiO}-\mathrm{SZ}$ supports.

- Lowering the yttria content from $5.8 \mathrm{~mol}^{\%} \mathrm{YO}_{1.5}$ to $4.9 \mathrm{~mol} \%$ dramatically decreased the HTD resistance of the tetragonal zirconia phase in SOC supports. The 4.9 $\mathrm{YO}_{1.5}$-SZ based support had around $35 \%$ monoclinic phase after $850 \mathrm{~h}$ of aging at $800{ }^{\circ} \mathrm{C}$. On the other hand, Ce-Y co-doped compounds possessed superior HTD and LTD resistance that is believed to be due to the additional stabilizing effect of $\mathrm{Ce}^{3+}$. Accordingly, lowering the stabilizer concentration to improve the fracture toughness of SOCs fuel electrode supports should be done with a Ce-Y co-doping approach. Furthermore, a suitable reduction profile is required to generate enough $\mathrm{Ce}^{3+}$ to prevent the phase transformation caused by LTD, HTD and upon reduction.

- The $1.5 \mathrm{CeO}_{2} 4.5 \mathrm{YO}_{1.5}$-SZ based support had approximately $18 \%$ higher room temperature fracture toughness compared to the $5.8 \mathrm{YO}_{1.5} \mathrm{SZ}$ based support after aging at $800{ }^{\circ} \mathrm{C}$ for $850 \mathrm{~h}$.

- The results suggest that $1.5 \mathrm{CeO}_{2} 4.5 \mathrm{YO}_{1.5} \mathrm{SZ}$ is a superior alternative to $5.8 \mathrm{YO}_{1.5-\mathrm{SZ}}$ providing improved fracture toughness and resistance to hydrothermal degradation (LTD and HTD) in solid oxide fuel or electrolysis cell supports. 


\section{Declaration of Competing Interest}

The authors declare that they have no known competing financial interests or personal relationships that could have appeared to influence the work reported in this paper.

\section{Acknowledgements}

The research leading to this work has been part of the SYNFUEL (sustainable synthetic fuels from biomass gasification and electrolysis) project. The authors wish to thank Innovation Fund, Denmark for the financial support of the project (File No. 4106-00006B). We would also like to thank Dr. Marie Lund Traulsen for her help with Raman measurements.

\section{Appendix A. Supplementary data}

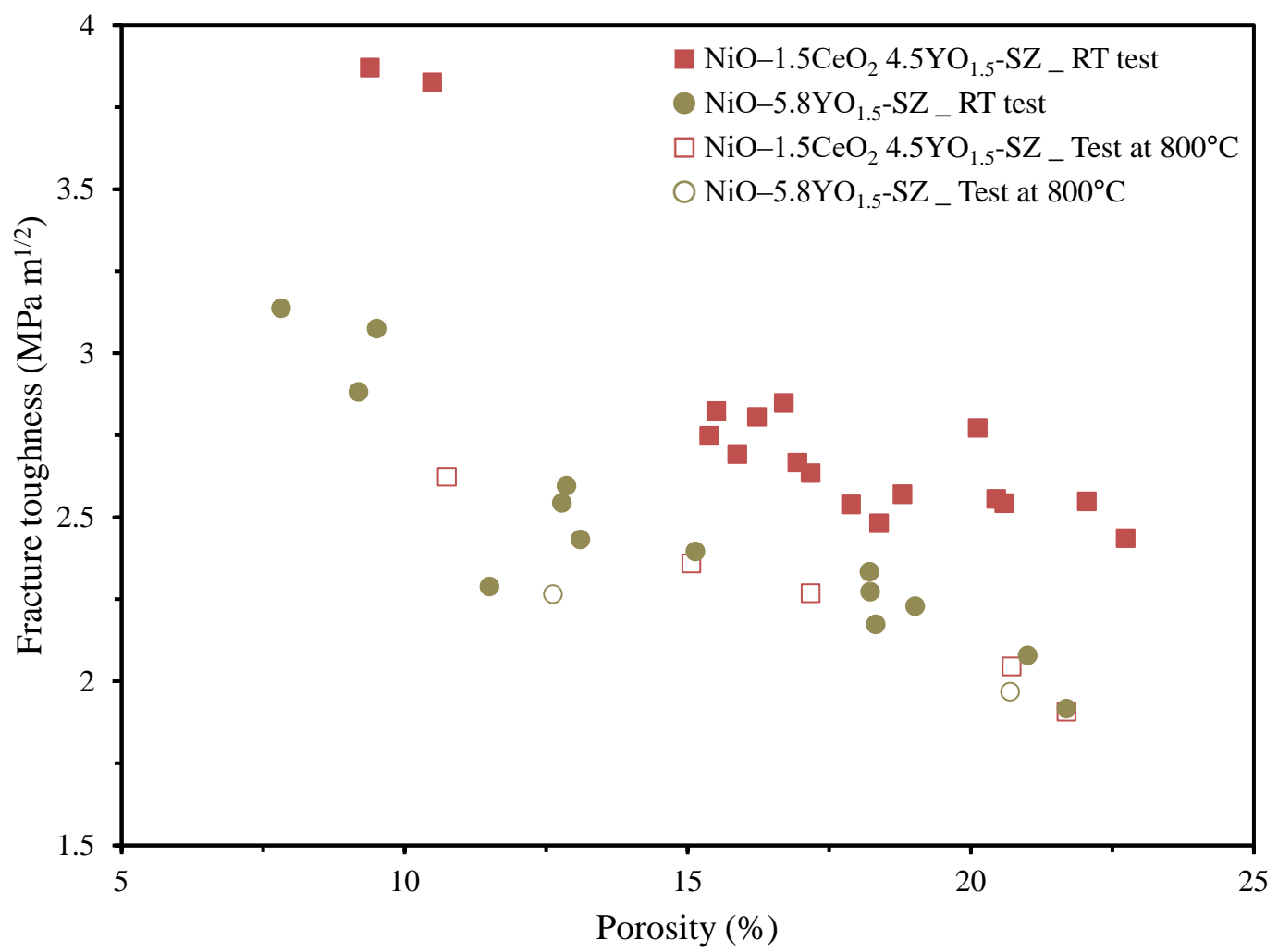

Figure 9. Fracture toughness of the $\mathrm{NiO}-1.5 \mathrm{CeO}_{2} 4.5 \mathrm{YO} 1.5-\mathrm{SZ}$ and the $\mathrm{NiO}-5.8 \mathrm{YO} 1.5-\mathrm{SZ}$ (state-of-the-art support) at room temperature and $800^{\circ} \mathrm{C}$ as a function of porosity (extracted from Figure 3 and Figure 4). 

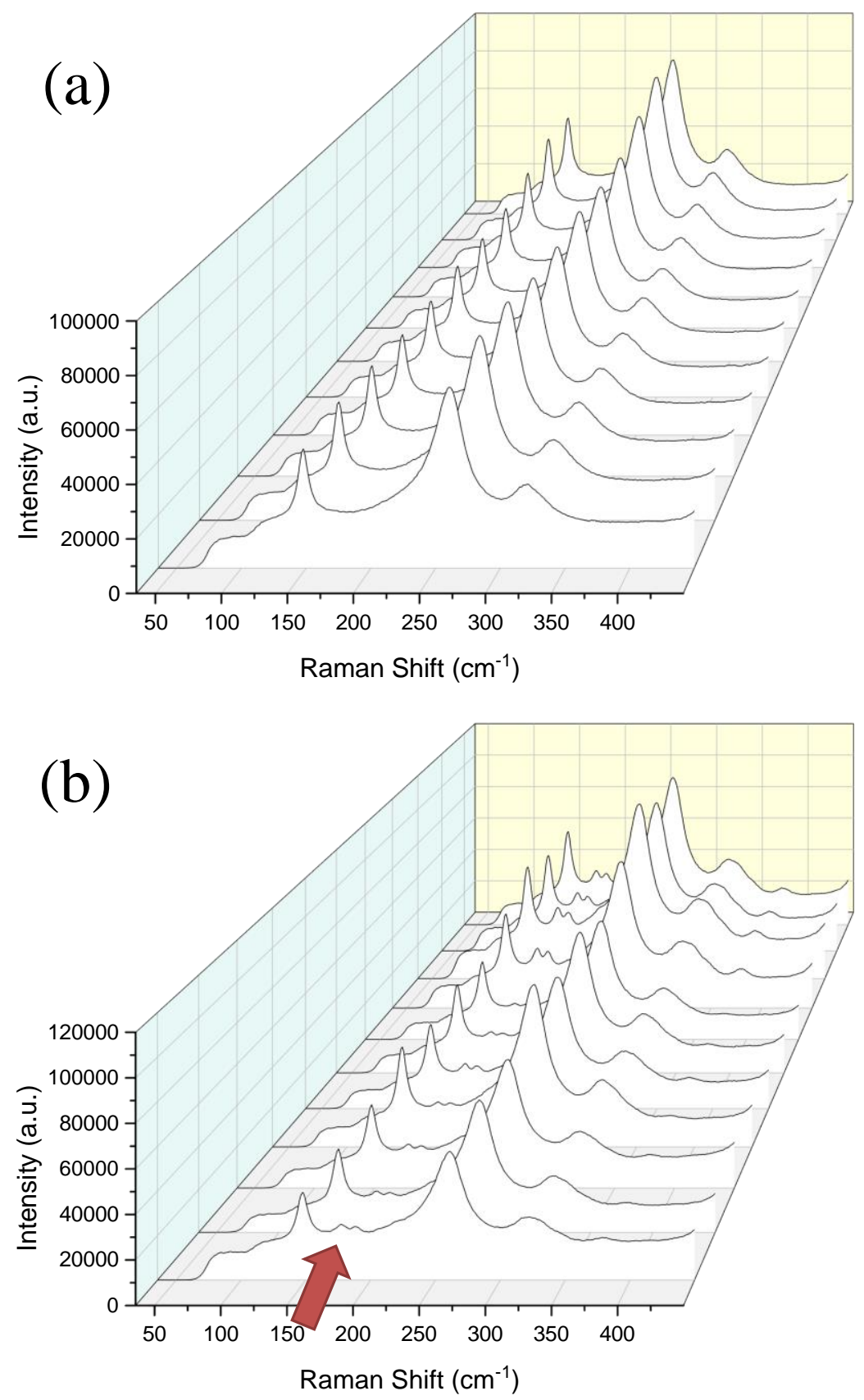

Figure 10. Typical Raman spectra of (a) surface and (b) fractured surface of NiO-5.8YO 1.5 -SZ support fractured at room temperature. Different curves show the spectra obtained at different points along a $20 \mu \mathrm{m}$ line (with $2 \mu \mathrm{m}$ span). The arrow shows the position of the characteristic peaks of the monoclinic phase. 

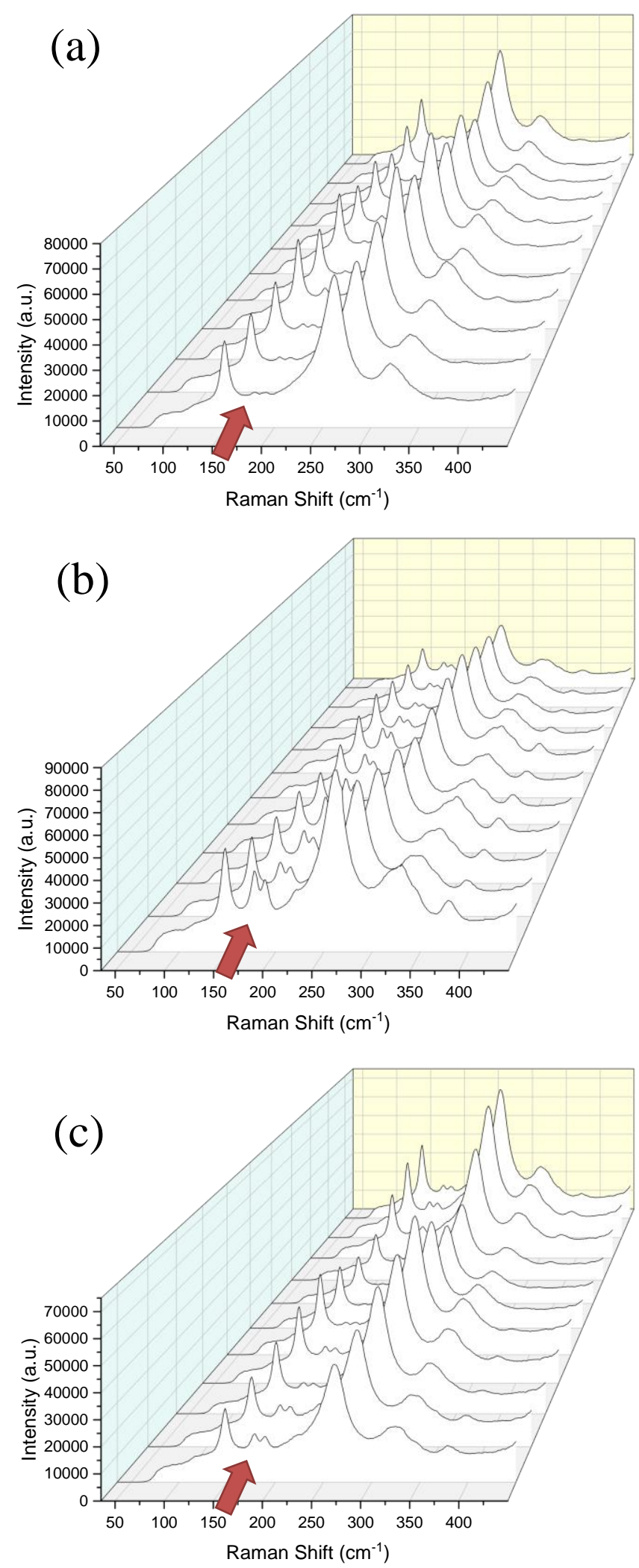

Figure 11. Typical Raman spectra of (a) surface and the fractured surface of NiO-4.9YO 1.5-SZ supports fractured at (b) room temperature and $(c) 800^{\circ} \mathrm{C}$. The characteristic peaks of the monoclinic phase (showed by the arrows) are observed in the figures. 


\section{$\underline{\text { References }}$}

1. M.A. Laguna-Bercero, Recent advances in high temperature electrolysis using solid oxide fuel cells: a review, J. Power Sources, 203 (2012), pp. 4-16

2. A.B. Stambouli, E. Traversa, Solid oxide fuel cells (SOFCs): a review of an environmentally clean and efficient source of energy, Renew. Sustain. Energy Rev., 6 (2002), pp. 433-455

3. T. Klemens $\varnothing$, D. Boccaccini, K. Brodersen, H.L. Frandsen, P.V. Hendriksen, Development of a novel ceramic support layer for planar solid oxide cells, Fuel Cells, 14 (2014), pp. 153-161

4. B. Charlas, D.W. Ni, H.L. Frandsen, K. Brodersen, M. Chen, Mechanical properties of supports and half-cells for solid oxide electrolysis influenced by alumina-zirconia composites, Fuel Cells, 17 (2017), pp. 132-143

5. K.C. Wincewicz, J.S. Cooper, Taxonomies of SOFC material and manufacturing alternatives, J. Power Sources, 140 (2005), pp. 280-296

6. W. Fischer, J. Malzbender, G. Blass, R.W. Steinbrech, Residual stresses in planar solid oxide fuel cells, J. Power Sources, 150 (2005), pp. 73-77

7. H.L. Frandsen, M. Makowska, F. Greco, C. Chatzichristodoulou, D.W. Ni, D.J. Curran, M. Strobl, L.T. Kuhn, P.V. Hendriksen, Accelerated creep in solid oxide fuel cell anode supports during reduction, J. Power Sources, 323 (2016), pp. 78-89

8. B. Charlas, H.L. Frandsen, K. Brodersen, P.V. Henriksen, M. Chen, Residual stresses and strength of multilayer tape cast solid oxide fuel and electrolysis half-cells, J. Power Sources, 288 (2015), pp. 243-252

9. A. Nakajo, J. Kuebler, A. Faes, U.F. Vogt, H.J. Schindler, L.K. Chiang, S. Modena, J. Van Herle, T. Hocker, Compilation of mechanical properties for the structural analysis of solid oxide fuel cell stacks. Constitutive materials of anode-supported cells, Ceram. Int., 38 (2012), pp. 3907-3927

10. J. Wei, J. Malzbender, Steady state creep of Ni-8YSZ substrates for application in solid oxide fuel and electrolysis cells, J. Power Sources, 360 (2017), pp. 1-10

11. J. Chevalier, C. Olagnon, G. Fantozzi, B. Calès, Crack propagation behavior of Y-TZP ceramics, J. Am. Ceram. Soc., 78 (1995), pp. 1889-1894

12. D.N. Boccaccini, H.L. Frandsen, S. Soprani, M. Cannio, T. Klemensø, V. Gil, P.V. Hendriksen, Influence of porosity on mechanical properties of tetragonal stabilized zirconia, J. Eur. Ceram. Soc., 38 (2018), pp. 1720-1735

13. H.L. Frandsen, T. Ramos, A. Faes, M. Pihlatie, K. Brodersen, Optimization of the strength of SOFC anode supports, J. Eur. Ceram. Soc., 32 (2012), pp. 1041-1052

14. S. Aruna, M. Muthuraman, K. Patil, Synthesis and properties of Ni-YSZ cermet: anode material for solid oxide fuel cells, Solid State Ion., 111 (1998), pp. 45-51

15. M. Radovic, E. Lara-Curzio, Mechanical properties of tape cast nickel-based anode materials for solid oxide fuel cells before and after reduction in hydrogen, Acta Mater., 52 (2004), pp. 5747-5756

16. S. Goutianos, H.L. Frandsen, B.F. Sørensen, Fracture properties of nickel-based anodes for solid oxide fuel cells, J. Eur. Ceram. Soc., 30 (2010), pp. 3173-3179

17. D.W. Ni, B. Charlas, K. Kwok, T.T. Molla, P.V. Hendriksen, H.L. Frandsen, Influence of temperature and atmosphere on the strength and elastic modulus of solid oxide fuel cell anode supports, J. Power Sources, 311 (2016), pp. 1-12

18. G. Pećanac, J. Wei, J. Malzbender, Fracture toughness of solid oxide fuel cell anode substrates determined by a double-torsion technique, J. Power Sources, 327 (2016), pp. 629-637

19. R.H.J. Hannink, P.M. Kelly, Barry C. Muddle, Transformation toughening in zirconiacontaining ceramics, J. Am. Ceram. Soc., 83 (2000), pp. 461-487 
20. B. Basu, Toughening of yttria-stabilised tetragonal zirconia ceramics, Int. Mater. Rev., 50 (2005), pp. 239-256

21. J. Chevalier, L. Gremillard, A.V. Virkar, D.R. Clarke, The tetragonal-monoclinic transformation in zirconia: lessons learned and future trends, J. Am. Ceram. Soc., 92 (2009), pp. 1901-1920

22. S. Shukla, S. Seal, Mechanisms of room temperature metastable tetragonal phase stabilisation in zirconia, Int. Mater. Rev., 50 (2005), pp. 45-64

23. I. Nettleship, R. Stevens, Tetragonal zirconia polycrystal (TZP) - a review, Int. J. High Technol. Ceram., 3 (1987), pp. 1-32

24. J.D. Lin, J.G. Duh, The use of X-ray line profile analysis in the tetragonal to monoclinic phase transformation of ball milled, as-sintered and thermally aged zirconia powders, J. Mater. Sci., 32 (1997), pp. 4901-4908

25. J.-D. Lin, J.-G. Duh, Crystallite size and microstrain of thermally aged low-ceria- and low-yttria-doped zirconia, J. Am. Ceram. Soc., 81 (1998), pp. 853-860

26. J.D. Lin, J.G. Duh, Correlation of mechanical properties and composition in tetragonal CeO2-Y2O3-ZrO2 ceramic system, Mater. Chem. Phys., 78 (2002), pp. 246-252

27. J.-D. Lin, J.-G. Duh, Fracture toughness and hardness of ceria-and yttria-doped tetragonal zirconia ceramics, Mater. Chem. Phys., 78 (2002), pp. 253-261

28. J.-D. Lin, J.-G. Duh, C.-L. Lo, Mechanical properties and resistance to hydrothermal aging of ceria-and yttria-doped tetragonal zirconia ceramics, Mater. Chem. Phys., 77 (2002), pp. 808-818

29. J.G. Duh, M.Y. Lee, Fabrication and sinterability in Y2O3-CeO2-ZrO2, J. Mater. Sci., 24 (1989), pp. 4467-4474

30. P. Khajavi, Y. Xu, H.L. Frandsen, J. Chevalier, L. Gremillard, R. Kiebach, P.V. Hendriksen, Tetragonal phase stability maps of ceria-yttria co-doped zirconia: from powders to sintered ceramics, Ceram. Int., 46 (2020), pp. 9396-9405

31. A. Suresh, M.J. Mayo, W.D. Porter, C.J. Rawn, Crystallite and grain-size-dependent phase transformations in yttria-doped zirconia, J. Am. Ceram. Soc., 86 (2003), pp. 360362

32. F.F. Lange, Transformation toughening-Part 3 Experimental observations in the ZrO2-Y2O3 system, J. Mater. Sci., 17 (1982), pp. 240-246

33. S. Ramousse, M. Menon, K. Brodersen, J. Knudsen, U. Rahbek, P.H. Larsen, Manufacturing of anode-supported SOFC's: processing parameters and their influence, ECS Trans. S, 7 (2007), pp. 317-327

34. M. Pihlatie, A. Kaiser, P.H. Larsen, M. Mogensen, Dimensional behaviour of Ni-YSZ anode supports for SOFC under RedOx cycling conditions, ECS Trans., 7 (2007), pp. $1501-1510$

35. D. P. Williams, A. G. Evans, A simple method for studying slow crack growth, J. Test. Eval., 1 (1973), pp. 264-270

36. E.R. Fuller Jr, An Evaluation of Double-torsion Testing — Analysis, (1979) Google Scholar

37. H. Toraya, M. Yoshimura, S. Somiya, Calibration curve for quantitative analysis of the monoclinic-tetragonal ZrO2 system by X-Ray diffraction, Commun. Am. Ceram. Soc., 67 (1984), pp. C119-C121

38. B. Kim, J. Hahn, K.R. Han, Quantitative phase analysis in tetragonal-rich tetragonal / monoclinic, J. Mater. Sci. Lett., 16 (1997), pp. 669-671

39. M. Ghatee, M.H. Shariat, J.T.S. Irvine, Investigation of electrical and mechanical properties of 3YSZ/8YSZ composite electrolytes, Solid State Ion., 180 (2009), pp. 5762

40. M. Backhaus-Ricoult, SOFC - A playground for solid state chemistry, Solid State Sci., 10 (2008), pp. 670-688 
41. S. A. Nightingale, H.K. Worner, D.P. Dunne, Microstructural development during the microwave sintering of Yttria-Zirconia ceramics, J. Am. Ceram. Soc., 80 (1997), pp. 394-400

42. J. Kondoh, H. Shiota, K. Kawachi, T. Nakatani, Yttria concentration dependence of tensile strength in yttria-stabilized zirconia, J. Alloys. Compd., 365 (2004), pp. 253-258

43. M.M.R. Boutz, A.J.A. Winnubst, A.J. Burggraaf, Yttria-ceria stabilized tetragonal zirconia polycrystals - sintering, grain-growth and grain-boundary segregation, J. Eur. Ceram. Soc., 13 (1994), pp. 89-102

44. S. Stemmer, J. Vleugels, O. Van Der Biest, Grain boundary segregation in high-purity, yttria-stabilized tetragonal zirconia polycrystals (Y-TZP), J. Eur. Ceram. Soc., 18 (1998), pp. 1565-1570

45. P. Khajavi, J. Chevalier, P. Vang Hendriksen, J.W. Tavacoli, L. Gremillard, H. Lund Frandsen, Double Torsion testing of thin porous zirconia supports for energy applications: toughness and slow crack growth assessment, J. Eur. Ceram. Soc., 40 (2020), pp. 3191-3199

46. F. Zhang, H. Reveron, B.C. Spies, B. Van Meerbeek, J. Chevalier, Trade-off between fracture resistance and translucency of zirconia and lithium-disilicate glass ceramics for monolithic restorations, Acta Biomater., 91 (2019), pp. 24-34

47. A. Kuzjukevics, S. Linderoth, Influence of NiO on phase stabilization in 6 mol\% yttriastabilized zirconia, Mater. Sci. Eng. A, 232 (1997), pp. 163-167

48. X.C. Song, J. Lu, T.S. Zhang, J. Ma, Sintering behavior and mechanisms of NiO-doped 8 mol\% yttria stabilized zirconia, J. Eur. Ceram. Soc., 31 (2011), pp. 2621-2627

49. A. Kuzjukevics, S. Linderoth, Interaction of NiO with yttria-stabilized zirconia, Solid State Ion., 93 (1997), pp. 255-261

50. H. Kondo, T. Sekino, T. Kusunose, T. Nakayama, Y. Yamamoto, K. Niihara, Phase stability and electrical property of NiO-doped yttria-stabilized zirconia, Mater. Lett., 57 (2003), pp. 1624-1628

51. J.T. White, I.E. Reimanis, J.R. O'Brien, Solubility of NiO in pechini-derived ZrO2 examined with SQUID magnetometry, J. Mater. Sci., 47 (2012), pp. 1690-1696

52. P.M. Delaforce, J.A. Yeomans, N.C. Filkin, G.J. Wright, R.C. Thomson, Effect of NiO on the phase stability and microstructure of yttria-stabilized zirconia, J. Am. Ceram. Soc., 90 (2007), pp. 918-924

53. F.F. Lange, Transformation toughening - Part 3 Experimenta observations in the ZrO2- Y2O3 system, J. Mater. Sci., 17 (1982), pp. 240-246

54. M. Mori, T. Yamamoto, H. Itoh, H. Inaba, H. Tagawa, Thermal expansion of nickelzirconia anodes in solid oxide fuel cells during fabrication and operation, $J$. Electrochem. Soc., 145 (1998), pp. 1374-1381

55. M.R. Notis, R.M. Spriggs, W.C. Hahn, Elastic moduli of pressure-sintered nickel oxide, J. Geophys. Res., 76 (1971), pp. 7052-7061

56. H. Hayashi, T. Saitou, N. Maruyama, H. Inaba, K. Kawamura, M. Mori, Thermal expansion coefficient of yttria stabilized zirconia for various yttria contents, Solid State Ion., 176 (2005), pp. 613-619

57. J. Luo, R. Stevens, Porosity-dependence of elastic moduli and hardness of 3Y-TZP ceramics, Ceram. Int., 25 (1999), pp. 281-286

58. A. Selçuk, A. Atkinson, Elastic properties of ceramic oxides used in solid oxide fuel cells (SOFC), J. Eur. Ceram. Soc., 17 (1997), pp. 1523-1532

59. F.R. Chien, F.J. Ubic, V. Prakash, A.H. Heuer, Stress-induced martensitic transformation and ferroelastic deformation adjacent microhardness indents in tetragonal zirconia single crystals, Acta Mater., 46 (1998), pp. 2151-2171 
60. G.S.A.M. Theunissen, J.S. Bouma, A.J.A. Winnubst, A.J. Burggraaf, Mechanical properties of ultra-fine grained zirconia ceramics, J. Mater. Sci., 27 (1992), pp. 44294438

61. M. Trunec, Effect of grain size on mechanical properties of 3Y-TZP ceramics, Ceram. - Silikáty, 52 (2008), pp. 165-171

62. K. Tsukuma, M. Shimada, Strength, fracture toughness and Vickers hardness of CeO2stabilized tetragonal ZrO2 polycrystals (Ce-TZP), J. Mater. Sci., 20 (1985), pp. 11781184

63. M. Mazaheri, A.M. Zahedi, M.M. Hejazi, Processing of nanocrystalline 8 mol\% yttriastabilized zirconia by conventional, microwave-assisted and two-step sintering, Mater. Sci. Eng. A, 492 (2008), pp. 261-267

64. M. Mazaheri, M. Valefi, Z.R. Hesabi, S.K. Sadrnezhaad, Two-step sintering of nanocrystalline $8 Y 203$ stabilized $\mathrm{ZrO} 2$ synthesized by glycine nitrate process, Ceram. Int., 35 (2009), pp. 13-20

65. M. Radovic, E. Lara-Curzio, G. Nelson, Fracture toughness and slow crack growth behavior of Ni-YSZ and YSZ as a function of porosity and temperature, Adv. Solid Oxide Fuel Cells II Ceram. Eng. Sci. Proc. (2008), pp. 373-381

66. H.-Y. Zhu, T. Hirata, Y. Muramatsu, Phase separation in 12 mol\% ceria-doped zirconia induced by heat treatment in $\mathbf{H} 2$ and Ar, J. Am. Ceram. Soc., 75 (1992), pp. 2843-2848

67. K.-H. Heussner, N. Claussen, Strengthening of ceria-doped tetragonal zirconia polycrystals by reduction-induced phase transformation, J. Am. Ceram. Soc., 72 (1989), pp. 1044-1046

68. J. Vleugels, C. Zhao, O. Van Der Biest, Toughness enhancement of Ce-TZP by annealing in argon, Scr. Mater., 50 (2004), pp. 679-683

69. C. Zhao, J. Vleugels, B. Basu, O. Van Der Biest, High toughness Ce-TZP by sintering in an inert atmosphere, Scr. Mater., 43 (2000), pp. 1015-1020

70. S. Maschio, O. Sbaizero, S. Meriani, Mechanical properties in the ceria-zirconia system, J. Eur. Ceram. Soc., 9 (1992), pp. 127-132

71. M. Matsuzawa, M. Abe, S. Horibe, J. Sakai, The effect of reduction on the mechanical properties of $\mathrm{CeO} 2$ doped tetragonal zirconia ceramics, Acta Mater., 52 (2004), pp. 1675-1682

72. J. Chevalier, L. Gremillard, Zirconia as a biomaterial, Compr. Biomater. II (2017), pp. 122-144

73. R. Kubrin, G. Blugan, J. Kuebler, Influence of cerium doping on mechanical properties of tetragonal scandium-stabilized zirconia, J. Eur. Ceram. Soc., 37 (2017), pp. 16511656 